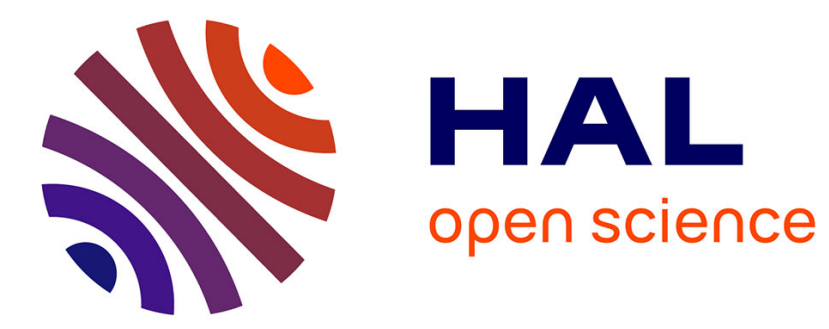

\title{
Financial structure in the age of Globalization Thi-Hong-Hanh Pham
}

\section{- To cite this version:}

Thi-Hong-Hanh Pham. Financial structure in the age of Globalization. 2013. hal-00822790

\author{
HAL Id: hal-00822790 \\ https://hal.science/hal-00822790 \\ Preprint submitted on 15 May 2013
}

HAL is a multi-disciplinary open access archive for the deposit and dissemination of scientific research documents, whether they are published or not. The documents may come from teaching and research institutions in France or abroad, or from public or private research centers.
L'archive ouverte pluridisciplinaire HAL, est destinée au dépôt et à la diffusion de documents scientifiques de niveau recherche, publiés ou non, émanant des établissements d'enseignement et de recherche français ou étrangers, des laboratoires publics ou privés. 


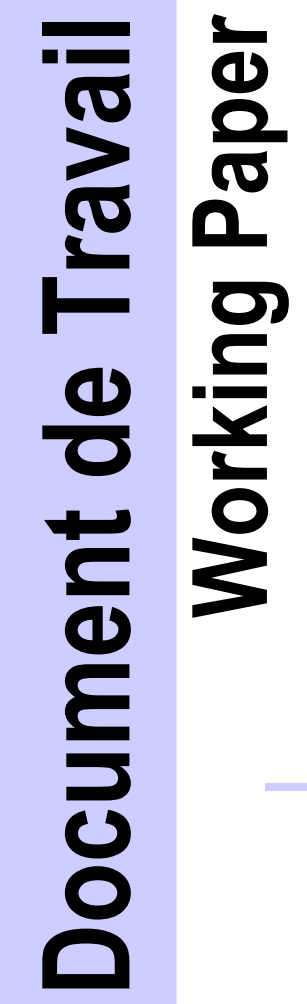

\title{
Financial structure in the age of Globalization
}

\author{
PHAM Thi Hong Hanh
}

2013/04

*LEMNA - Université de Nantes

INSTITUT

d'ECONOMIE

et de MANAGEMENT

de NANTES - IAE

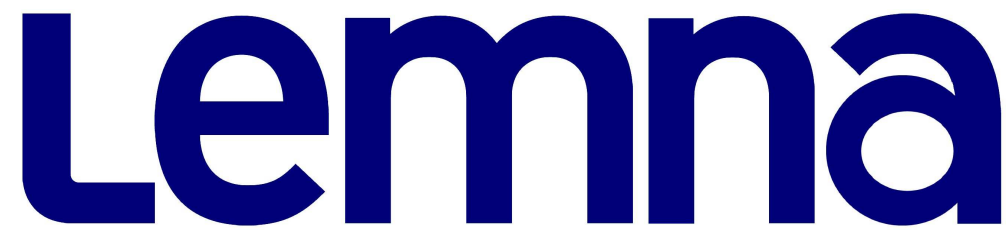

EA 4272 


\title{
Financial structure in the age of Globalization
}

(Version Mars, 2013)

\section{PHAM Thi Hong Hanh ${ }^{1}$}

\author{
LEMNA, Institute of Economics and Management, University of Nantes \\ Chemin de la Censive du Tertre, BP 52231, 44322 Nantes Cedex 3, FRANCE \\ Phone: +33(0)2 40141733 \\ Fax: +33 (0)2 40141650 \\ E-mail: thi-hong-hanh.pham@,univ-nantes.fr
}

\begin{abstract}
Using a large panel dataset covering 150 countries over the period 1990-2010, this paper aims to address the question of how financial structure changes when economies are liberalised and access international capital markets. Specifically, in this study, globalisation is characterised not only by trade and financial integration but also by other important aspects, such as social globalisation, political globalisation and cultural globalisation as well. Our empirical results, by and large, support globalisation's impacts on financial structure, which are, however, diverse and strongly depend on the way to measure globalisation and financial structure. The empirical finding also reveals a dynamic change in financial structure after the globalisation process, except the case of low-income countries, in which financial structure seems to be not correlated with either globalisation process or other macroeconomic variables.
\end{abstract}

Keywords: Globalisation; Financial structure; Panel data analysis

JEL: F01; F50; G10; G29

\footnotetext{
${ }^{1}$ The author gratefully acknowledges financial support from the Chair Finance of the University of Nantes Research Foundation.
} 


\section{Introduction}

Over the last decade, globalisation has become a phenomenal aspect of the world economy. In terms of trade globalisation, by 2008, the ratio of trade flows to the world GDP valued at around $60 \%$, compared with less than $40 \%$ in the mid-1990s. Similarly, in terms of cross-border financial transactions, FDI net flows reached more than $6 \%$ of the world GDP, while this figure only attained to less than $2.5 \%$ in the mid-1990s. ${ }^{2}$ By and large, globalisation process is believed to strongly affect the world economic growth in particular and all macroeconomic aspects in general. Among others, this paper pays a special attention to a possible causal link running from globalisation to the changes in financial structure, which has seemed to be ignored in the recent literature.

Unlike a knowledge lack in the impacts of globalisation on financial structure, there is a large body of research studying the links between financial structure and economic growth, the composition of industrial development, and corporate finance. The motivation of these works is to resolve the question of what kind of financial system (bank-based versus market-based financial systems) is particularly conductive to new firm formation, existing firm expansion, industrial success, and overall economic growth. According to Levine (2000), although overall financial development is robustly linked with economic growth, there is no support for either the bank-based or the marketbased view. Together with a contentious theoretical debate about the comparative advantages of bank-based and market-based systems, empirical work over the last decade has begun investigating the interaction between financial development and economic integration. For instance, Baltagi et al. (2009) find that both trade and financial openness are statistically significant determinants of financial development and that financial system of closed economies can benefit most by opening up both their trade and capital accounts, while in an earlier influent contribution, Rajan and Zingales (2003) suggest that opening up one without the other could have a negative impact on financial development. However, both these well-known studies have only examined the role of trade and financial globalization in explaining the development of domestic financial systems, but not yet resolved the question of whether the globalization process motivates the change in financial structure of a country. On the other hand, globalisation is manifold dimensions: economic (including trade and financial), social, political, cultural, environmental and so forth. Although the existing literature has already examined the impacts of globalisation's financial and trade aspect, other important aspects of this process have been still unexplored.

For these reasons, our present paper tends to clarify the multidimensional impacts of globalisation on the change in domestic financial structure by using a large panel dataset of around 150 countries during the period 1990-2010. Two specific issues will be questioned, as follows:

2 Author's computation from WDI data 
- Does globalisation process influence the structure of domestic financial system?

- What kind of financial system, bank-based or market-based, is favoured in the globalisation process?

To do so, we introduce in all estimation regressions various indicators capturing the manifold dimensions of globalisation and the characteristics of a domestic financial system. We first employ the Ordinary Least Square (OLS) technique to estimate the regressions of interest. We also use the Instrumental Variable (IV) estimator that allows controlling for simultaneity bias and reverse causality running from explicative variables to financial structure. This paper is organized as follows. Section reviews the theoretical background that motivates our empirical analysis. Section 3 sets up the data. Section 4 presents our empirical strategy. Section 5 reports and analyses the empirical results. Concluding remarks are in Section 6.

\section{Theoretical framework}

The existing literature contributes four views in financial structure: the bank-based view; the market-based view; the finance and law view; and the financial services view. In light of bank-based view, the banking system plays a positive role in: (i) acquiring information about firms, monitoring managers and then (Diamond, 1984; Ramakrishnan and Thakor, 1984); (ii) identifying good projects and managing risk sharing (Allen and Gale, 1999; Bencivenga and Smith, 1991); and (iii) improving capital allocation to exploit economies of scale (Sirri and Tufano, 1995). However, Rajan (1992) argues that acquiring expensive information about firms allows the banking system to extract firms' large rents. To avoid losing an important part of the potential profits to banks, firms could not undertake the high-return but high-risk projects. In other worlds, the bank-based systems favor the low-risk but low-return projects, which may retard innovation and economic growth (Morck and Nakamura 1999). Thus, the market-based view stresses that financial markets will reduce the inherent inefficiencies associated with the banking systems and thereby encourages the new technologies and fosters overall economic growth. For instance, Beck and Levine (2002) support the determinant role of financial markets in promoting economic success by facilitating diversification and the customization of risk management. In contrast, financial markets' functions are criticised by the bank-based view's proponents. According to Bhide (1993), in financial markets, investors have fewer incentives to exert rigorous corporate control since they can inexpensively sell their shares. Consequently, the development of financial market can reduce corporate control and then hinder economic growth. Furthermore, greater banking systems can facilitate industrial expansion by forcing firms to reveal information and repay their debts (Rajan and Zingales, 1998). 
Unlike the bank-based versus market-based debate, the law and finance view suggests that the legal system plays a determinant role in ensuring the effectiveness of the financial system and thereby facilitates innovation and growth (La Porta, Lopez-de-Silanes, Shleifer, and Vishny, 1997, 1998, 2000; henceforth LLSV). As mentioned in LLSV (2000) “...bank-versus market-centeredness is not an especially useful way to distinguish financial systems". The LLSV works instead suggest that the legal systems effectively protect outside investors, promote overall financial development and then overall national economy. Similar to the law and finance view, the financial services view developed by Merton and Bodie $(1995)$ and Levine $(1997,2005)$ minimizes the importance of the bank-based versus market-based debate. According to these authors, the main issue is not bankbased or market-based system. The importance is ensuring an environment in which intermediaries and markets provide sound and effective services. In an orthodox literature survey, Levine (2004) identifies and summarizes five key functions of financial system through which it can facilitate economic growth: (i) Producing information ex ante about possible investments and allocating capital; (ii) Monitoring investments and exerting corporate governance; (iii) Facilitating the trading, diversification, and management of risks; (iv) Facilitating the exchange of goods and services; and ( $v$ ) Mobilizing and pooling savings. Regard to the empirical literature, Levine (2002) argues that distinguishing countries by financial structure (bank-based or market-based) does not allow assessing cross-country differences in long-run economic performance. According to Levine, although overall financial development is robustly links with economic growth, there is no support for either the bank-based or the market-based view. Yet, evidence on transitional economies suggests that the financial systems of the most successful countries among a group of twelve transitional countries are strongly dominated by banking sector (Berglof and Bolton, 2002). Unlike a rich literature, either theoretical or empirical, on the finance-growth nexus, the structural change in financial systems in the world more and more globalized has been still underdeveloped. Furthermore, the existing literature has seemed to partially explore this issue as investigating the link between the development of each financial system (bank-based versus market-based) and globalization process, which is only captured by financial and trade integration. In terms of supply-side, one influent contribution is the hypothesis initialed by Rajan and Zingales (2003). They argue that interest groups and especially industrial and financial incumbents are frequently worried by the financial development that can create opportunities for the entry of new firms resulting in breeding competition and eroding incumbents' profits. In this context, incumbents have strong incentives to resist the financial development. Rajan and Zingales indicate that the opposition to financial development will be weaker if a country is more open to both trade and foreign capital flows. Using a panel data of 24 countries mostly industrialized during the period 1913-1999, they find that the simultaneous opening of both trade and capital accounts holds the 
key to successful financial development. Rajan and Zingales' hypothesis has been considered as an important prediction in the empirical literature, which lends itself to other rigorous empirical analysis in the same field. With respect to Rajan and Zingales' hypothesis and using the measure of "natural openness" favoured by Frankel and Romer (1999), Huang and Temple (2005), first, support that openness and finance are strongly associated for higher-income countries, but not for lower - income. Secondly, applying the Granger causality method for a 40-years and 88-countries dataset, they conclude the strong effects of trade openness on financial development in the whole sample for lower-income countries, but not for higher income countries. In another empirical work, using a dynamic panel technique - the GMM estimator, Baltagi et al. (2009) address the empirical question of whether trade and financial openness can help explain the recent pace in financial development, as well as its variation across countries in recent year. According to the authors, although a country can benefit most by opening both its trade and capital accounts, opening up one without the other could still encourage the banking development. Most recently, based on a sample of 29 Asian developing countries over 1994-2008, Pham (2010) finds evidence of a bidirectional causality between trade openness and financial development. The author also argues that this relationship is still concluded even under the impact of financial crises. Overall, the findings in each above empirical contribution seem to be diverse. The main reason is that in each contribution, the model specifications are not identical, the estimations procedures are not the same and the datasets and data frequencies used for estimation are quite different.

In terms of demand-side, Svaleryd and Vlachos (2002) ask the question of whether institutions allowing for better insurance possibilities and risk diversification within a country are positively related to a liberal trade regime. In particular, they investigate whether the development of domestic financial markets is systematically related to trade policy. They argue that openness may be associated with greater risks, including exposure to extend demand shocks or foreign competition. Openness to trade will create new demands for external finance, which in turn encourage financial markets' development to diversify financial risks and to allow firms overcoming short-term cash flow problems or adverse shocks. In this sense, the effects of trade on finance are likely to work primarily through the demand side. Trade openness and financial development may also be linked in other ways. In a cross country study, Levine and Renelt (1992) identify a robust correlation between openness and the share of investment in GDP. They also show that trading economies with a high investment level may promote their financial development. On the other hand, according to Acemoglu and Zilibotti (1999), if greater openness makes relative performance evaluation easier, this would encourage market-based financial intermediation rather than direct monitoring. Finally, developing a model of sovereign lending, 
Spiegel and Rose (2004) suggest that if a credible threat to reductions in trade occurs then one should observe more lending occurring between countries whose trading links are stronger.

In general, all above outlined works focus on the ways in which economic integration, in particular financial and trade integration, and the development of either overall financial system or each component of financial system (bank versus market systems) are connected. However, it should be noteworthy that these works have ignored the dynamic change in financial structure over the last decades. On the other hand, while globalization process is manifold dimensions (economic, social, political, cultural, environmental and so forth), the previous cited studies have only deepened our understanding of financial and trade openness' impacts on domestic financial systems. These knowledge gaps motivate us to investigate the potential impacts of different globalization dimensions on financial structure change.

\section{Data issues}

This section describes the data on which our empirical study is based. We begin with an outline of the financial structure measures, globalisation indicators and other macroeconomic variables. It is followed by the data setting. ${ }^{3}$

\subsection{Measures of financial structure}

"How to measure the financial structure?" has been a growing concern in the financial economics. In this paper, following the previous empirical works (e.g. Beck et al., 2001; Huang, 2005), we use a broad set of different indicators of financial structure. Each of these measures is constructed in respect to the principle that higher values imply more market-based financial system.

The first one is Structure-Activity, which compares the activity of stock markets with that of banks. This indicator is defined as the log of the ratio of Value Traded and Bank Credit. Value traded refers to the total value of stocks traded as a share of GDP. Bank Credit equals the claims of the banking sector on the private sector as a share of GDP. According to Levine (2000), the structureactivity indicator indicates procedure intuitively appealing classification of national financial systems as well as highlights potential anomalies. Together with the structure-activity indicator, we use two alternative measures of financial structure as follows:

- Structure-Size indicator indicates the size of stock markets relative to that of the banking sector. The size of stock markets is measured by the market capitalisation ratio, which equals the value of domestic equities listed on domestic exchange divided by GDP. The size of bank is always captured by the bank credit ratio.

\footnotetext{
${ }^{3}$ Appendix A provides information on four country sub-samples. Appendix B contains the description and sources of all variables under consideration.
} 
- Structure-Efficiency indicator is defined as the efficiency of stock markets relative to that of banking systems. This indicator is measured by the product of Overhead Costs and Stock market turnover.

The previous empirical work (e.g. Beck et al., 2001; Levine, 2000) also uses the fourth financial structure measure - Structure-Aggregate indicator that is the principal component of the size, activity and efficiency structure measures. However, this index is not introduced in our present paper. The reason is that the Structure-Activity and Structure-Efficiency indexes are computed from the WDI database while the Structure-Efficiency index is collected from the database developed by Beck et al. (2001). In order to avoid the result bias resulting from the incompatibility in data sources, we do not, therefore, construct the principal component of these three main indicators.

\subsection{Globalisation indicators}

As mentioned, globalisation is manifold dimensions. In this paper, we pay our attention to two main dimensions of globalisation process, notably economic and non-economic dimensions. In order to capture the non-economic dimensions of globalisation, we use the dataset developed by the Zurich-based Konjunkturforschungsstelle (KOF) (Dreher et al., 2008), which proposes three social globalization indicators and one political globalization indicator. Likewise, we classify the economic dimensions of globalization process into three sub-dimensions:

- First, to measure the general degree of economic globalization of a given country we use the "Actual economic flows" indicator provided by Dreher et al. (2008). This indicator presents a weighted average of trade, foreign direct investment, portfolio investment and income payments to foreign nationals.

- Second, the financial dimension of globalization is measured through two alternative indicators being considered as "de facto" one or "de jure" one. According to Baltagi et al. (2009), to provide a useful summary of the financial integration progress of a country, one should use the ratio of foreign assets and liabilities to GDP as a de-facto indicator. This indicator is initially constructed by Lane and Milesi-Ferretti (2006). However, due to the data unavailability, we use the share of FDI inflows in GDP instead of Lane and MilesiFerretti's index. The "de jure" indicator is the Chinn and Ito (2006) index of capital account openness (KAOPEN) that is widely used in previous cross-country studies.

- Third, we use a broad set of indicators to measure the level of trade globalisation. The first one is the trade openness indicator. Among others, the most well-known trade openness indicator is the Sachs and Warner (1995) index. ${ }^{4}$ Although this index serves as a proxy for a

\footnotetext{
4 The SW index, which is constructed by Sachs and Warner (1995), is a dummy variable for openness based on five individual dummies for specific trade-related policies. Relying on this index, a country is classified as closed if it
} 
wide range of policy and institutional differences and not only of trade policy (Rodriguez and Rodrik, 1999), it can only suggest that a country is either open or closed. This index is also difficultly constructed due to the unavailability of many data components. Besides, the statistical correlation between the SW index and other variables of interest is not always obvious and difficult to set an econometric model and to interpret the empirical results. For these reasons, we employ two other standard trade openness indicators measured by exports/GDP and imports/GDP. The second one is a set of de jure trade openness indicators including: i) Most-favoured nation (MFN) rate; ii) trade concentration index; and iii) trade diversification index.

\subsection{Other variables}

Remind that this paper aims to investigate the possible impacts of globalisation process on the change in financial structure. However, in order to avoid a potential model uncertainty problem resulting from the bias of variable inclusion/exclusion, we introduce other macroeconomic variables in all regressions. We select the additional variables by following the empirical work developed by Huang (2005). In this work, applying the Bayesian Model Averaging (BMA) and General-to-specific (Gets) approaches, Huang selects, from a wide range of macroeconomic variables, a subset of potential determinants of financial development. Here, we reuse these variables classified into different categories: the country size; institutional quality; macroeconomic policy; and geographic characteristics.

Firstly, we employ three indicators, including GDP growth rate; GDP per capita and population (in $\log$ value) to capture the level of economic development. The fact is that the link between finance and economic growth has been widely concluded in the literature, either theoretical or empirical. So that, introducing these indicators should be required in all regressions. On the other hand, the quadratic term for GDP per capita is also included in order to allow for the possible nonlinear effect of economic growth on the change in financial structure. Together with the previous economic development variables, we use two other variables to consider the impacts of macroeconomic stability on financial structure, notably the annual level of inflation (INF) and the difference between official exchange rate and black market's exchange rate (EXR).

Secondly, regarding to the institutional quality, we introduce a set of five alternative variables. The first one (LEG dummies) considers the impact of legal origin on financial structure. This dummy (LEG1 through LEG5) takes into consideration five different legal origins: British origin; French 
origin; socialist origin; German origin; and Scandinavian origin. The second one POLITY2 is the democracy index that reflects government type and institutional quality based on freedom of suffrage, operational constraints and balances on executives, and respect for other basic political rights and civil liberties. ${ }^{5}$ POLITY2 ranges from -10 to 10 with higher values representing more democratic regimes. The third one DURABLE is the political stability index, using the number of years since the last regime transition or independence. The fourth one PCI measures narrowly the constraints on the executive. All of these three indexes POLITY2, DURABLE and PCI are derived by (Marshall et al., 2003). The last one is a widely-used indicator of the quality of government in a broader sense (labelled GQ), which is suggested by Kaufmann et al. (2010), derived by averaging six measures of government quality: voice and accountability, political stability and absence of violence, government effectiveness, light regulatory burden, rule of law, and freedom from graft.

Thirdly, our present paper also tends to examine the impacts of initial level of financial development on the subsequent change in financial structure. Due to the data availability, we should exclusively focus on the pooled, cross-section, time-series results, where the data are pooled over the periods of 5 years. Nonetheless, it is enough to simply replace the averaged values of financial indicators over 1990-2010 by the 1989 value. Thus, to capture the impacts of initial level of financial development, we simply use two financial development indicators in 1989 - the Private Credit to GDP and the Capitalization Value to GDP (labeled BANK1989 and MARKET1989, respectively).

Finally, to capture the influence of geographic indicators, we include a set of eight regional dummies, which is also favoured in Huang (2005), including: East Asia and Pacific (EAP); East Europe and Central Asia (EECA); Middle East and North African (MENA); West Europe (WE), North American (NA); South Asian (SA); Sub Saharan African (SSA); and Latin America and Caribbean (LAC). To this end, we also consider another geographic variable - the area variable (AREA in the log value).

\subsection{Data setting}

On one hand, we exclude the transition economies and small economies with a population of less than 500,000 in 2000 from our analysis. The information on the transition economies and population size are from the World Bank Global Development Network Database (GDN) and the World Development Indicators (2011) respectively. On the other hand, in order to avoid the potential problem of heterogeneity in cross-country economic development level, there are five

\footnotetext{
${ }^{5}$ This index is so-called the "combined polity score", equal to the democracy score minus the autocracy score. The democracy and autocracy scores are derived from six authority characterises (regulation, competitiveness and openness of executive recruitment; operational independence of chief executive or executive constraints; and regulation and competition of participation). Based on these criteria, each country is assigned a democracy score and autocracy score ranging from 0 to 10.
} 
data samples on which the estimation is based: (i) the whole sample; (ii) high-income (HI) sample; (iii) low-income (LI) sample; (iv) lower middle-income (LMI) sample; and (v) upper middle-income (UMI) sample. Two remarks may rise from this data setting. Firstly, for the whole sample, in order to consider the different level of cross-country income, we additionally consider in each econometric investigation a set of income binary dummies, which capture four different levels of income: low, lower middle, upper middle and high. Secondly, the high income country sample include both OECD and non - OECD countries.

\section{$<$ Insert Table 1>}

The data sets are summarised in Table 1 that provides means and standard deviations of all dependent key variables (overall, between and within countries). Additionally, Table 1 provides the correlation coefficients between financial-structure variables and all dependent variables. It can be seen that all financial structure indicators display considerable variation both between and within countries, justifying the use of panel estimation techniques, which should allow the identification of the various parameters of interest. As shown in Table 1, almost correlation coefficients are significant that aids the modelling and help to confirm the choice of dependent variables. However, the values of correlation coefficient are diverse, ranging from negative to positive, from small to important. For instance, we find a positive and significant value of correlation coefficients between financial structure and the ratio exports/GDP, while the correlation coefficients between financial structure and the ratio imports/GDP are statistically insignificant. Looking at financial openness indicators, financial structure is much less correlated to the de facto than the de jure openness measures. Besides, the financial structure indicators seem to be strongly and positively correlated with social and political globalisation. Regarding other explanatory variables, the correlation coefficients between these variables and financial structure are positive and quite important. Finally, it is also noteworthy that there is such an important and positive correlation, ranging from 0.38 to 0.65 , between three financial structure indicators. We also calculate the correlation coefficients between financial structure indicators and all explanatory variables under consideration for each data sample (but are not reported to save space). The empirical results show that the magnitudes, the statistical significance even the sign of correlation coefficient have been more or less altered. Thus, we should not be surprised to see different empirical results for different data samples.

\section{Empirical strategy}

Our present paper aims to explain the change in financial structure as well as its variation across countries. Given this aim, our empirical strategy tries to make maximum use of both time and 
cross-country dimensions of available annual dataset. The empirical model is formulated as follows:

$$
\operatorname{lnFS}_{i t}=\beta_{0}+\beta_{1} \operatorname{lnGLO} O_{i t}+\beta_{2} \operatorname{lnMCRO}_{i t}+\beta_{3} F D_{i}^{1989}+\beta_{4} L A W_{i}+\beta_{5} I N S T_{i t}+\beta_{6} D U M_{t}+u_{i t}(1)
$$

where FS is an indicator of financial structure; GLO represents the globalization indicators; MCRO represents the macroeconomic variables; $F D^{1989}$ is the initial level of financial development in 1989; $L A W$ represents the legal origin of each country; INST is the institutional quality; DUM is income and regional dummies; and $u$ is an error term that contains country and time specific fixed effects. According to Equation 1, financial structure seems to be determined by the globalization dimensions (trade, financial, social and political) alongside a set of conditioning variables including the past history of financial development, the stage of economic development, captured by per capita income and economic growth, the institutional environment, and all time-invariant country specific factors such as geography characteristics and unchanging legal origin factor. Different hypotheses regarding the interaction term between financial structure and dependent variables imply different predictions on estimated coefficients' values. In detail, different hypotheses tested in this paper are as follows:

- First, a small increase in any globalization dimension would result in a change in financial structure. This would certainly be the case if the coefficients $\left(\beta_{1}\right)$ are significant. If one or more of these coefficients is not significant while the others are significant, it means that the globalization process partially influences the financial structure.

- Second, Boyd and Smith (1998) argue that banks are particularly important at low levels of economic development. As income rises, countries benefit from becoming more marketbased. This hypothesis would be supported if the coefficients $\left(\beta_{2}\right)$ associated with per capita income and economic growth are positive.

- Third, Rajan and Zingales (1998) suggest that bank-based systems have a comparative advantage in economies with weak legal systems. In these countries, powerful banking system can still force films to reveal information and pay their debts. In this context, economies will benefit from becoming more market-based only as their legal system capabilities strengthen. According to this view, we expect to find a significant and positive value of coefficients $\left(\beta_{5}\right)$.

- Finally, according to King and Levine (1993), the initial level of financial development is positively and significantly correlated with the level of subsequent financial development. In this light, we suppose that the initial level of financial development could also affect the subsequent change in financial structure. This view predicts that the coefficients $\beta_{3}$ should be positive or negative, which depends on the different measures of financial development. 


\section{Empirical analysis}

This section reports the empirical results of both the Ordinary Least Squares (OLS) estimation and the Instrumental Variables (IV) estimation. It also outlines the results' implications for the considered theoretical hypotheses and discuses policy recommendations.

\subsection{Estimations results}

Table 2 represents the empirical results using the OLS estimation with heteroskedasticityconsistent standard errors for the full data sample. As reported in Table 4, the impacts of globalisation aspects as well as other macroeconomic variables on financial structure are much diverse and strongly depend on the way to measure financial structure.

\section{$<$ Insert Table 2>}

\section{Impacts of globalisation aspects}

Going straight to the hypothesis of interest, we note that in the financial structure-activity regression, all "de facto" measures of trade openness are not statistically significant. This means that the change in structure-activity of domestic financial system does not depend on the level of trade openness. By contrast, the trade integration seems to be significantly related to financial Structure-size at least the 5\% significance level. Accordingly, more the country opens to trade, more the structure-size of domestic financial system changes. The export/GDP and import/GDP ratios are negatively correlated with financial structure-size at least the $5 \%$ significance level, suggesting that the development of exports and imports activities increases the size of bank-based financial system in comparison with that of market-based financial system. This result may be explained in two ways. On one hand, the trade policy based on exports promotion is designed to attract more private firms into exporting by offering help in product and market identification as well as providing financial and credit services. The growth of private sectors' credit demand, in turn, becomes a factor of deepening the banking-system. On the other hand, the negative relationship between imports and financial structure-size can be justified by the fact that an increase in credit demand, which results from a rising demand for financing imports flow, once again, promotes the development of domestic banking system. These both reasons support that the growth of exports and imports is one of the main channels strengthening the size of banking system compared to that of financial market system.

Following Table 2, we also find that trade integration differently influences financial structureefficiency. While exports variable enters with positive but non-significant coefficient, the impact of imports and total trade flows is economically meaningful and significant at the $10 \%$ level. For instance, an increase of $1 \%$ in imports and in total trade flow leads to an increase of $0.924 \%$ and a decrease of $1.438 \%$ in financial structure-efficiency, respectively. In other words, the imports growth results in a greater efficiency of market-based system, while general trade growth seems to 
improve the efficiency of bank-based system. Unlike such a diverse impact of "de facto" trade openness on financial structure, we observe that FDI inflow - which is used as a "de facto" financial openness - significantly and positively influences all financial structures measures at the $1 \%$ level. The values of inward FDI coefficients are, however, pretty small. According to this result, inward FDI should be considered as a potential factor mattering for structural change in domestic financial sector, particularly from a bank-based to a market-based system.

Examining now the de jure openness indicators, we first note that the de jure trade openness indicators partially enter in the estimation regressions with statistically significant coefficient. For instance, an increase in the MFN index can lightly decrease the value of all three financial structure indicators. Thus, the MFN index should be considered as a political tool to control the change in domestic financial structural. Otherwise, the empirical results only support the significantly negative impact of the exports concentration index on financial structure-size indicator. The structure-size indicator is also positively influenced by the KAOPEN index - a "de jure" financial openness measure, implying that capital account liberalisation spurs market-based system development once a threshold level of legal development has been attained. We now turn our attention to the link between other globalisation indicators and financial structure. It is worth noting that none of the estimated coefficients associated with the actual economic flow index and political globalisation index enters with a significantly statistical value. By contrast, we observe that the social globalization index positively but weakly affects the financial structure-activity. It means that the development of social globalisation process, which is measured by a combination of personal contacts, information flows and cultural proximity, promotes the stock value traded in particular and favours the financial market's activity in general.

\section{Impacts of macroeconomic environment}

As mentioned in the previous section, this paper also tends revisit the hypothesis, suggested by Boyd and Smith (1998), about the connection between the level of economic development and financial structure. First, we note that income per capita and economic growth rate are statistically significant determinants of financial structure at least the $5 \%$ level. The positive estimated coefficients of these variables strongly support the theoretical consideration of Boyd and Smith that as income rises, countries can benefit from becoming more market-based. For this reason, economic development leads to a gradual change in financial structure from a bank-based to a market-based system. Moreover, the significant and negative values of the quadratic GDP per capita variable imply a nonlinear relationship between economic development and financial structure. It indicates that economic development has positive effect on financial structure below threshold level, but beyond the estimated threshold, economic development has negative effect on financial structure. In the other words, as the level of economic development arises, domestic 
financial system becomes more market-based but at a decreasing rate over time. While economic development plays an important role in determining the financial structure, other macroeconomic variables, notably inflation and exchange rates difference, do not significantly enter in the financial structure regressions.

Another hypothesis tested in this paper is the possible interaction between the initial level of financial development and financial structure. As shown in Table 2, the initial level of both banking and financial market development has no impact on determining the financial structureactivity. Regarding to other financial structure regressions, we note that the initial level of banking development enters in both structure-size and structure-efficiency regressions with a positive and significant coefficient of around 0.486 and 1.27, respectively. This result indicates that a higher initial level of banking development allows the market-based system functioning more efficiently. Similarly, a greater initial level of market development also helps a country to improve the subsequent size of market-based system. In general, the initial level of financial development is partially linked with the subsequent change in financial structure from a classical bank-based to a modern market-based system.

\section{Impacts of institutional and legal environment}

As mentioned above, in this paper we also re-examine the possible relationship between financial structure and legal and institutional system outlined by Rajan and Zingales (1998) and La Porta et al. (1998). First, we note that among others, only the government quality index significantly influences financial structure, but its impact is diverse and weak. This indicator significantly enters with a positive estimated coefficient in the structure-size regression, but with a negative estimated coefficient in the structure-efficiency regression. The other institutional quality measures (including the democracy index, the political stability index, and the constraints on the executive index) are not significantly related to financial structure. None of these institutional quality indicators significantly enters in any financial structure regression at least the $10 \%$ level. The statistical estimated values of these indicators are, moreover, pretty small in all regressions. Second, contradictory to the result on institutional quality's impact, we find that financial structure significantly depends on the legal origin. Specifically, almost different legal origins tend to support a more bank-based financial system rather than a more market-based financial system. Overall, the impacts of legal and institutional system on financial structure seem to be diverse. This may be due to the heterogeneous level of economic development in our full data sample, even though we have introduced in all regressions a set of dummies considering the different level of economic development.

We now look at the dummies reflecting the differences in economic development level and geographical zone. It is generally worth noting that most of these dummies have not any impact in 
changing the financial structure, except the two following cases. First, the coefficient of North America region dummy is significantly negative of around -0.294 and -0.365 the structure-activity and structure-size regressions, respectively. Second, the OECD dummy also enters with a negative and significant coefficient of around -0.25 in the same regression. This implies that there is a changing financial structure phenomenon in the high income countries, in particularly in North America region. Interestingly, in these countries that are well-known for their developed marketbased system, the domestic financial sector's structure has been altering in favour of bank-based system. This issue is also graphically supported in Figure 1, which displays the change in financial structure-size following the change in trade openness indicator in all countries at any income level.

\section{<Insert Figure 1>}

From Figure 1, we first observe that in the low-income countries, the relationship between trade openness and financial structure-size is not clear-cut. Between 2000 and 2010, the trade openness indicator has tended to increase, while the value of financial structure-size indicators has not changed. In particular, a market-based financial system has not been developed in almost of these countries. Second, the lower middle-income countries have experienced a stable value of trade openness but a lightly increasing trend in financial structure-size indicator, meaning that their domestic financial system has become more and more market-based, in particular in the case of emerging markets such as Indonesia and India. Regarding the upper middle-income countries, the co-movement between trade openness and financial structure is not also clear. In some countries (e.g. Mexico, Russia...) a stable value of trade openness is followed by an increase in financial structure-size value. In other countries (e.g. Argentina, Turkey...), the financial system has a tendency of becoming more bank-based. Specifically, the second global largest economy, China, has experienced a sharp increase in trade openness, however no significant change in financial structure-size from 2000 to 2010. Looking at the case of high-income countries, Figure 1 displays a sharply changing trend in financial structure-size. In detail, the development of banking system seems to be faster than that of market system, while the trade openness indicator seems to be stable in the "old" industrial countries. Regarding now three new industrial countries, while Korea and Singapore do not evidence any clear-cut dynamics of financial structure and trade openness, Hong Kong has experienced not only a remarkable growth of international trade but also an important change in its financial structure. Hong Kong's trade openness index has increased from $282 \%$ to $440.3 \%$, and its financial structure-size indicator has been nearly tripled (2.4 to 6.4 ) over the period 2000-2010.

On the whole, the impacts of either globalisation variables or other explanatory variables on financial structure are diverse. These impacts vary across countries at different level of economic development, and also depend on the way to measure globalisation aspects and financial 
structure. For this reason, in the next step, we re-examine all hypotheses of interest for different country groups in order to avoid the possible biased results due to the heterogeneity of economic development levels.

\section{Empirical results for different data sub-samples}

As stated above, basing on four different levels of economic development, we simply split the full data sample four sub-samples: low income, lower-middle income, upper middle-income, and high-income. For each country sample, we also reuse the OLS technique with heteroskedasticityconsistent standard errors to re-estimate Equation 1, in which all income level dummies are excluded. We report all empirical results in Tables 3.1-4. Here, we only discuss only the results complementing to and differencing from those of the full data sample.

\section{<Insert Table 3>}

First, it is worth emphasising that almost explanatory variables enter in all estimation regressions with insignificant coefficients for the LI countries sample. The fact is that among thirty-two countries in the low-income sample there are only seven countries in which the domestic financial sector contains both bank-based and market-based systems. ${ }^{6}$ Moreover, in these countries, the value of all financial structure indicators is pretty small over the period 1990-2010 due to the lessdevelopment of their financial markets. Thus, no dynamic change in financial structure of lowincome countries explains why the value of almost estimated coefficients is not statistically significant.

Second, the empirical results of the LMI sample provide only partial support to those of the full sample. We find that the de facto openness indicators, either trade or financial, have no impact on financial structure. Looking at the de jure openness indicators, trade diversification index influences significantly and negatively the financial structure-activity indicator, meaning that trade diversification can stimulate activities of banking system in the LMI countries. On the other hand, the estimated coefficient of both political globalization and political durability indexes becomes significantly positive but fairly small in financial structure-activity and structure-efficiency regressions. This suggests that the political evolution in this country group tends to encourage the development of banking system. Besides, the empirical results also support that the change in LIM countries' financial structure, from bank-based to more market-based system, is particularly taking place in South-Asia region. Another different and interesting result is that financial structure is positively associated with the initial level of financial development. So that, the initial level of financial development can be considered as one of the main factors making the subsequent financial structure of LMI countries become more market-based.

\footnotetext{
${ }^{6}$ Including Bangladesh, Kenya, Malawi, Nepal, Tanzania, Uganda, and Zimbabwe
} 
Third, compared to the low and lower middle-income sample, the results of upper middle-income sample seems to be more consistent with those of the full sample. Meanwhile, there are still a few different results. For instance, the trade diversification index enters in all financial structure regressions with a significant and negative coefficient. This means that a trade concentration policy can alter financial structure of UMI countries in favour of bank-based system. The UIM countries have also experienced the diverse relationships between financial structure and initial level of financial development. As reported in Table 3.3, financial structure negatively depends on the initial level of banking development, but positively links to the initial level of financial market development. In other word, if the initial banking system was well developed, the UIM countries are willing to maintain a subsequent financial system more bank-based, and vice versa.

Turning now to the high-income sample, we first note that the empirical results support, by and large, those of the full sample. On one hand, we find the diverse impacts of globalisation process on financial structure of high-income countries. On the other hand, macroeconomic situation (e.g., the economic development level and the initial level of financial development) and institutional environment also play a determinant role in explaining the change in the high-income's financial structure. Moreover, most of regional dummies enter in the financial structure-size regression with negative and significant coefficient at the $1 \%$ level, confirming the fact that domestic financial system becomes more and more bank-based not only in North America but also in other highincome countries.

\section{$<$ Insert Table 4>}

To this end, stressing the possible impacts of globalisation on financial structure in different data sub-samples allows us to avoid the potential heterogeneous problem. The main empirical results are synthesized in Table 4 . They are, by and large, consistent with and complementary to those of the full sample, except the case of low-income sample in which we fail to determine financial structure in function of different regressors under consideration. This exceptional finding can be explained by the fact that financial structure in low-income countries has not altered over the time. Most of these countries have experienced a less-developed domestic financial sector, in which market-based system's activities are not much considered and even absent.

\subsection{Sensitivity of empirical results}

This sub-section carries out a set of robustness checks to examine the results' sensitivity to alternative estimation strategies and data sub-samples. As mentioned above, in the low-income sub-sample, financial structure seems to not depend on either globalisation indicators or other explanatory variables. It means that including or excluding low-income countries in the full sample might not change the main findings. Thus, the first robustness check involves re-estimating 
the full sample without low-income countries' data. The results of OLS estimator with heteroskedasticity-consistent standard errors reported in Table 5 show that omitting low-income countries does not alter the conclusions, only the magnitudes of estimated coefficients are little affected.

\section{$<$ Insert Table 5>}

The second referred robustness check is the Instrumental Variable (IV) estimator that can correct the country-specific and time-specific effects and allows getting rid of any endogeneity in explanatory variables. However, determining the IV in each estimated gravity equation is not an easy task. On one hand, we treat all de facto openness terms (including trade and FDI) as endogenous using a set of instruments: the trade concentration and diversification indexes; the most-favoured nation rate, and the KAOPEN index. These instruments are plausible exogenous drivers of a country's trade and financial openness, respectively, and are unlikely or much less correlated with its financial structure. On the other hand, we treat the initial level of financial development as endogenous using some additional instruments suggested by related literature. The first one is initial income measured by 1989 GDP per capita. Including this variable as an instrument is stimulated by work such as Greenwood and Smith (1997) on the feedback from economic growth to financial development. Second, according to a large number of rigorous empirical works (e.g. Baltagi et al., 2009), both type of openness, either trade or financial are statistically significant determinants of financial development. In this vein, we consider the initial levels of openness (notably the KAOPEN index in 1989, the FDI/GDP1989 and Trade/GDP1989 indicators) as the second instrumental variable.

\section{$<$ Insert Table 6>}

Above all, we test for the validity of each instrumental variable. In the lower part of Table 6, we report the weak instrument test suggested by Stock and Yogo (2002) and the Hansen/Sargan test of over-identifying restrictions. On one hand, in the weak instrument test the Cragg-Donald Fstatistics are superior to the critical value of $10 \%$ maximal IV size proposed by Stock and Yogo (2002), meaning that the null hypothesis of weak instruments is rejected. On the other hand, the Sargan/Hansen test of over-identifying restrictions, which is reported in the last line, checks the validity of the instruments. According to the empirical results, we cannot reject the null hypothesis of Sargan/Hansen test meaning that the instruments are valid instruments, notably uncorrelated with the error term, and that the excluded instruments are correctly excluded from the estimated equation.

We now look at the IV estimator's main results reported Table $6 .^{7}$ The IV results are, by and large, similar to those of the OLS estimator in terms of sign and significance, but the magnitudes are

7 We only report the results of IV estimator for the full data sample to save space. Other results are available if required 
different as would be expected. The explanatory variables enter with much smaller coefficient than using the OLS technique. It remains, however, highly significant. Otherwise, the IV estimator provides two complementary results to those of OLS estimator. First, when we treat the openness variables as endogenous, the export variables (EX) become negative and significant at least the $10 \%$ level in all regressions, while the import variables (IM) retain their estimated coefficients and signs. Besides, when the financial openness is treated as endogenous, its level of significance drops from $5 \%$ to $10 \%$. In general, imports are less sensitive to endogeneity bias than either exports or inward FDI. Second, when we treat the initial level of financial development as endogenous, the initial development of financial market loses significance and so does the interaction term, while the initial development of banking system retains positive and significant at the $1 \%$ level. Thus, the market-based system seems more susceptible to endogeneity bias than the banking-based system. This is perhaps not too surprising given that the bank-based system is a fundamental form of financial sector, while creating the market-based system, which reflects a modern form of financial sector, strongly depends on other macroeconomic variables.

\section{Conclusion}

Our empirical findings on the link between the components of financial structure and globalization aspects and other covariates are, by and large, insensitive to a range of datasets and estimation methods. For instance, omitting the low-income countries in the dataset does not alter the conclusions. Furthermore, when we restrict the sample to just LMI countries, UMI countries and HI countries, the basic results of the impacts of globalization on financial structure hold, while others results are affected but qualitatively not too dissimilar. On the other hand, using the IV estimator to treat the openness and initial level of financial development as endogenous gives similar results to those of OLS estimator.

Our empirical results, by and large, support the impacts of globalisation's multidimensional aspects on financial structure. However, these impacts are diverse and relatively depend on the way to measure globalisation and financial structure. The impacts of globalisation process are also heterogeneous across country. Precisely, our finding reveals a dynamic change in developing countries' financial structure after the globalisation process. However, the financial structure in developed countries has seemed to be less influenced by the extent of their participation in the

global economy. By contrast, the emerging countries (e.g. Hong Kong, India and so forth) have experienced the determinant role of globalisation in making their domestic financial system become more market-based.

To this end, the present paper is complementary to the existing literature that has only focused on the one-way linkage running from financial structure to economic growth. Moreover, our results offer an important blessing for policy makers in the country aspiring to change their financial 
structure by stimulating their socio-economic integration, since opening up both trade and capital accounts may provide an effective stimulus to financial structure change. However, the opportunities to change financial structure through the globalization process may be limited in low-income countries.

\section{References}

Acemoglu, D., and Zilibotti, F., 1999. "Information Accumulation in Development", Journal of Economic Growth, 4/1, pp.5-38.

Allen, F., and Gale, D., 1999. "Comparing Financial systems", MIT Press, Cambridge, MA.

Baltagi, B.H., Demtriades, P.O, and Law, S.H., 2009. "Financial development and openness: Evidence from panel data", Journal of Development economics, 89, pp.285-96.

Beck, T., and Levine, R.., 2002. "Industry growth and capital allocation: Does having a market- or bank-based system matter?" Journal of Financial Economics, in press.

Beck, T., Demirguc-Kunt, A., and Levine, R., 2001. The financial structure database, in "Financial Structure and Economic Growth: A Cross-country Comparison of Banks, Markets, and Development" (A. Demirguc-Kunt and R. Levine, Eds.), pp. 17-80. MIT Press, Cambridge, MA.

Bencivenga, V.R., and Smith, B.D., 1991. "Financial intermediation and endogenous growth", Review of Economic Studies, 58, pp.195-209.

Berglof, E., and Bolton, P., 2002. "The great divide and beyond: Financial architecture in transition", Journal of Economic Perspectives, 16, pp. 77-100.

Bhide, A., 1993. "The hidden costs of stock market liquidity", Journal of Financial Intermediation, 34, pp.1-51.

Boyd, J. H., and Smith, B. D., 1998. "The evolution of debt and equity markets in economic development", Economic Theory, 12, pp.519-60.

Chinn, M.D., and Ito, H., 2006. "What matters for financial development? Capital controls, institutions and interactions", Journal of Development Economics, 81, pp.163-92.

Diamond, D., 1984. "Financial intermediation and delegated monitoring", Review of Economic Studies, 51, pp. 393-414.

Dreher, A., Gaston, N., Martens, P. 2008. Measuring globalization: Gauging its consequence. New York, Springer.

Frankel, J. A., and Romer, D., 1999. “Does trade cause growth?”, American Economic Review, 89, pp. 379-98.

Greenwood, J., and Smith, B. D., 1997. "Financial markets in development, and the development of Financial markets", Journal of Economic Dynamics and Control, 21, pp. 145-81.

Huang, Y., 2005. «What determines financial development », CEPR Discussion Paper, No. 05/580.

Huang, Y., and Temple, J., 2005. "Does external trade promote financial development?", CEPR Discussion Paper, No. 5150.

Kaufmann, D., Kraay, A., and Massimo, M., 2010. "The Worldwide Governance Indicators : A Summary of Methodology, Data and Analytical Issues", World Bank Policy Research Working Paper, No. 5430

King, R.G., and Levine, R., 1993. "Finance and growth: Schumpeter might be right", Quarterly Journal of Economics, 108, pp.717-37.

La Porta, R., F. Lopez-de-Silanes, A. Shleifer, and Vishny, R. W. 1997. “Legal determinants of external finance", Journal of finance, 52/, pp.1131-50.

La Porta, R., F. Lopez-de-Silanes, A. Shleifer, and Vishny, R. W., 1998. "Law and finance”, Journal of Political Economy, 106, pp. 1113-55.

Lane, P.R., and Milesi-Ferretti, G.M., 2006. "The external wealth of nations Mark II: revised and extended estimates of foreign assets and liabilities 1970-2004", IMF Working Paper 06/69.

Laporta, R., Lopez-de-Silanes, F., Shleifer, A., and Vishny, R. W., 2000. “ Investor protection and corporate governance", Journal of Financial Economics, 58, pp.3-27. 
Levine, R. 2005. "Finance and Growth: Theory and Evidence," Handbook of Economic Growth, in: Philippe Aghion \& Steven Durlauf (ed.), Handbook of Economic Growth, pp. 865-934.

Levine, R., 1997. "Financial development and economic growth: Views and agenda", Journal of Economic Literature, 35, pp.688-726.

Levine, R., 2002. “Bank-Based or Market-Based Financial Systems: Which Is Better? », Journal of Financial Intermediation, 11, pp.398-428.

Levine, R., and Renelt, D., 1992. "A sensitivity analysis of cross-country growth regressions", American Economic Review, 82, pp.942-63.

Marshall, M. G. and Taeggers, K. J., 2003. Polity IV Project Country Reports, CIDUM, University of Maryland.

Merton, R. C., and Bodie, Z. (1995). A conceptual framework for analyzing the financial environment, in "The Global Financial System: A Functional Perspective" (D. B. Crane, K. A. Froot, S. P. Mason, A. F. Perold, R. C. Merton, E. R. Sirri, and P. Tufano, Eds.), pp. 3-32. Harvard Business School Press, Boston, MA.

Mork, R., and Nakkamura, M., 1999. "Banks and corporate control in Japan", Journal of Finance 54, pp.319340.

Pham, T.H.H., 2010. "Financial Development, Financial Openness and Trade Openness: New evidence », FIW Working Paper $\mathrm{N}^{\circ} 60$.

Rajan, R. G., 1992. "Insiders and outsiders: The choice between informed and arms length debt", Journal of Finance, 47, pp.1367-1400.

Rajan, R.G, and Zingales, L., 1998. "Financial dependence and growth", American Economic Review, 88/6, pp.559-586.

Rajan, R.G., and Zingales, L., 2003. "The great reversals: the politics of financial development in the twentieth century", Journal of Financial Economics, 69, pp.5-50.

Ramakrishnan, R.T.S., and Thakor, A.V., 1984. "Information reliability and a theory of financial intermediation", Review of Financial Studies, 51, pp.415-32.

Rodriguez, F., and Rodrik, D., 1999. Trade policy and economic growth: a skeptic's guide to cross -national evidence. NBER Working Paper, No.7081.

Rose, A.K., and Spiegel, M.M., 2004. "A Gravity Model of Sovereign Lending: Trade, Default, and Credit", IMF Staff Papers, 51, pp. 50-63.

Sachs, J., and Warner, A., 1995. "Economic reform and the process of global integration", Brookings Papers on Economic Activity, 1, pp.1-95.

Sirri, E. R., and Tufano, P. (1995). The economics of pooling, in "The Global Financial System: A Functional Approach" (D. B. Crane, K. A. Froot, S. P. Mason, A. F. Perold, R. C. Merton, E. R. Sirri, and P. Tufano, Eds.), pp. 81-128. Harvard Business School Press, Cambridge, MA.

Stock, J. H. and Yogo, M. (2002). 'Testing for weak instruments in linear IV regression', NBER Technical Working Paper No. 284. Cambridge, MA: NBER.

Svaleryd, H., and Vlachos, J., 2002. "Markets for risk and openness to trade: how are they related", Journal of International Economics, 57, pp.369-95. 
Appendix A: Country sample

Country sample

High income

(42)

Upper Middle income (42)

Lower Middle income (47)

\section{Low income}

(35)

\section{Countries}

OECD countries (29): Australia; Austria; Belgium; Canada; Czech Republic; Denmark; Estonia; Finland; France; Germany; Greece; Hungary; Ireland; Israel; Italy; Japan; Korea, Rep.; Netherlands ; New Zealand; Norway; Poland; Portugal; Slovak Republic; Slovenia; Spain; Sweden; Switzerland; United Kingdom; United States

Non-OECD countries (13) : Bahrain; Croatia; Cyprus; Equatorial Guinea; Hong Kong SAR, China; Kuwait; Oman; Puerto Rico; Qatar; Saudi Arabia; Singapore; Trinidad and Tobago; United Arab Emirates

Albania; Algeria; Argentina; Azerbaijan; Belarus; Bosnia and Herzegovina; Botswana; Brazil; Bulgaria; Chile; China; Colombia; Costa Rica; Cuba; Dominican Republic; Ecuador; Gabon; Iran, Islamic Rep; Jamaica; Jordan; Kazakhstan; Latvia; Lebanon; Libya; Lithuania; Macedonia, FYR; Malaysia; Mauritius; Mexico; Montenegro; Namibia; Panama; Peru; Romania; Russian Federation; Serbia; South Africa; Thailand; Tunisia; Turkey; Uruguay

Angola; Armenia; Bhutan; Bolivia; Cameroon; Congo, Rep.; Cote d'Ivoire; Djibouti; Egypt, Arab Rep.; El Salvador; Fiji; Georgia; Ghana; Guatemala; Guyana; Honduras; India; Indonesia; Iraq; Kiribati; Kosovo; Lao PDR; Lesotho; Mauritania; Moldova; Mongolia; Morocco; Nicaragua; Nigeria; Pakistan; Papua New Guinea; Paraguay; Philippines; Senegal; Sri Lanka; Sudan; Swaziland; Syrian Arab Republic; Timor-Leste; Turkmenistan; Ukraine; Uzbekistan; Vietnam; West Bank and Gaza; Yemen, Rep.; Zambia

Afghanistan; Bangladesh; Benin; Burkina Faso; Burundi; Cambodia; Central African Republic; Chad; Comoros; Congo, Dem. Rep.; Eritrea; Ethiopia; Gambia, The; Guinea; Guinea-Bissau; Haiti; Kenya; Korea, Dem. Rep.; Kyrgyz Republic; Liberia; Madagascar; Malawi; Mali ; Mozambique; Myanmar; Nepal ; Niger; Rwanda; Sierra Leone; Somalia; Tajikistan; Tanzania; Togo; Uganda; Zimbabwe 


\section{Appendix B: Data Description}

\begin{tabular}{|c|c|c|c|}
\hline & Variables & Definition & Source \\
\hline \multirow[b]{3}{*}{ 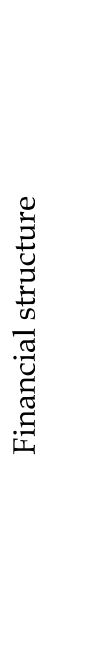 } & Structure-Activity & $\begin{array}{l}\text { Log of the ratio of Value Traded and Bank Credit to } \\
\text { private sectors }\end{array}$ & $\begin{array}{l}\text { Author's calculations from World } \\
\text { Development Indicators (WDI) }\end{array}$ \\
\hline & Structure-Size & $\begin{array}{l}\text { Log of the ratio of Capitalization market and Bank } \\
\text { Credit to private sectors }\end{array}$ & $\begin{array}{l}\text { Author's calculations from World } \\
\text { Development Indicators (WDI) }\end{array}$ \\
\hline & $\begin{array}{l}\text { Structure- } \\
\text { Efficiency }\end{array}$ & $\begin{array}{l}\text { The ratio of Overhead Costs and Stock Turnover: } \\
\text { - } \text { Overhead Costs: Accounting value of a bank's } \\
\text { overhead costs as a share of its total assets. } \\
\text { - Ratio of the value of total shares traded to } \\
\text { average real market capitalization, the } \\
\text { denominator is deflated using the following } \\
\text { method: Tt/P_at } /\left\{(0.5)^{*}\left[\mathrm{Mt} / \mathrm{P}_{-} \text {et }+\mathrm{Mt}-\right.\right. \\
1 / \mathrm{P} \text { et- } 1] \text { where } \mathrm{T} \text { is total value traded, } \mathrm{M} \text { is } \\
\text { stock market capitalization, P_e is end-of } \\
\text { period CPIP_a is average annual CPI }\end{array}$ & $\begin{array}{l}\text { World Bank's Financial Structure } \\
\text { and Economic Development } \\
\text { Database (FSED), } 2010\end{array}$ \\
\hline \multirow{6}{*}{ 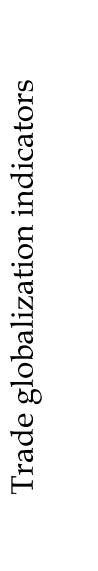 } & $\begin{array}{c}\text { Trade } \\
\text { diversification }\end{array}$ & $\begin{array}{l}\text { Diversification index of exports and imports of } \\
\text { countries and country groups }\end{array}$ & UNCTAD, 2011 \\
\hline & $\begin{array}{c}\text { Trade } \\
\text { concentration }\end{array}$ & $\begin{array}{l}\text { Concentration index of exports and imports of } \\
\text { countries and country groups }\end{array}$ & UNCTAD, 2011 \\
\hline & Exports & Share of exports in GDP & WDI, 2011 \\
\hline & Imports & Share of imports in GDP & WDI, 2011 \\
\hline & Trade openness & Sum of exports and imports as a share of GDP & WDI, 2011 \\
\hline & MFN rate & Applied MFN average duty & UNTAD, 2011 \\
\hline \multirow{3}{*}{ 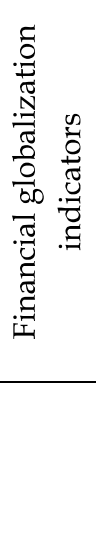 } & FDI & Inflows of FDI as a share of GDP & WDI, 2011 \\
\hline & $\begin{array}{l}\text { De jure financial } \\
\text { openness } \\
\text { (KAOPEN index) }\end{array}$ & $\begin{array}{l}\text { The Chinn and Ito (2006) index of capital account } \\
\text { openness is constructed from four binary dummy } \\
\text { variables codifying restriction on cross-border } \\
\text { financial transactions that are reported in the IMF's } \\
\text { Annual Report on Exchange Arrangements and } \\
\text { Exchange Restrictions }\end{array}$ & $\begin{array}{l}\underline{\text { http://www.ssc.wisc.edu/ mchi }} \\
\underline{\mathrm{nn} / \text { research.html }}\end{array}$ \\
\hline & $\begin{array}{l}\text { Actual economic } \\
\text { flows }\end{array}$ & $\begin{array}{l}\text { Index (0-100) representing a weighted average of } \\
\text { trade, foreign direct investment, portfolio investment } \\
\text { and income payments to foreign nationals }\end{array}$ & Dreher et al. (2008) \\
\hline \multicolumn{2}{|c|}{ Social Globalization } & $\begin{array}{l}\text { Index }(0-100) \text { of a weighted average of the indicators } \\
\text { on «Personal contacts» }(33 \%) \text {, «Information flows » } \\
(36 \%) \text {, and «Cultural proximity » }(31 \%)\end{array}$ & Dreher et al. (2008) \\
\hline & $\begin{array}{c}\text { Political } \\
\text { Globalization }\end{array}$ & $\begin{array}{l}\text { Index }(0-100) \text { of a weighted average of the indicators } \\
\text { on «Embassies in Country ", «Membership in } \\
\text { International Organizations », "Participation in U.N. } \\
\text { Security Council Missions », and «International } \\
\text { Treaties» }\end{array}$ & Dreher et al. (2008) \\
\hline
\end{tabular}


Other explanatory variables

\begin{tabular}{|c|c|c|c|}
\hline \multirow{3}{*}{ 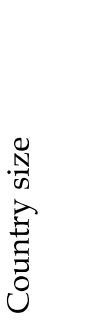 } & $\begin{array}{l}\text { GDP per capita } \\
\quad \text { (level) }\end{array}$ & $\begin{array}{l}\text { Gross Domestic Product per capita in constant US\$ } \\
2000 \text { prices }\end{array}$ & WDI, 2011 \\
\hline & GDP growth & Annual real GDP growth rate & WDI, 2011 \\
\hline & $\begin{array}{l}\text { Population } \\
\text { growth }\end{array}$ & Annual rate of change in population size & WDI, 2011 \\
\hline \multirow{4}{*}{ 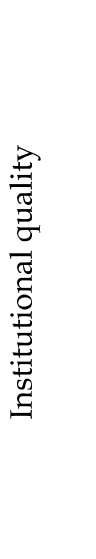 } & LEG (1-5) & Legal origin dummies & $\begin{array}{l}\text { Global Development Network } \\
\text { Database in World Bank (GDN), } \\
2010\end{array}$ \\
\hline & POLITY2 & Index of democracy & $\begin{array}{l}\text { PolityIV Database (Marshall et } \\
\text { al., 2003) (Updated by 2010) }\end{array}$ \\
\hline & GQ & The quality of government & Kaufmann et al. (2009) \\
\hline & PCI, & The constraints on the executive & Henisz (2000) (updated by 2010) \\
\hline \multirow{2}{*}{ 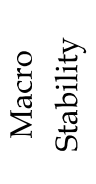 } & INF & Annual inflation level & WDI, 2011 \\
\hline & EXR & $\begin{array}{l}\text { The difference between official exchange rate and } \\
\text { black market's exchange rate }\end{array}$ & GDN, 2010 \\
\hline \multirow{2}{*}{ 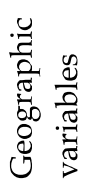 } & $\begin{array}{l}\text { Regional } \\
\text { dummies }\end{array}$ & $\begin{array}{l}\text { Six dummies determine the region for each country in } \\
\text { our sample }\end{array}$ & GDN, 2010 \\
\hline & AREA & Area (in log) in square kilometers & WDI \\
\hline \multirow{2}{*}{ 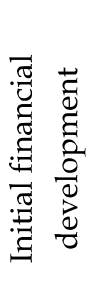 } & $\begin{array}{l}\text { Initial banking } \\
\text { system } \\
\text { development }\end{array}$ & Banking credit to private sectors 1989/GDP 1989 & WDI and IFS \\
\hline & $\begin{array}{l}\text { Initial market } \\
\text { system } \\
\text { development }\end{array}$ & Capitalization value 1989 / GDP 1989 & WDI and IFS \\
\hline
\end{tabular}


Table 1: Summary statistics and correlation: Full simple

\begin{tabular}{|c|c|c|c|c|}
\hline & & $\begin{array}{c}\text { Structure } \\
\text { activity }\end{array}$ & $\begin{array}{c}\text { Structure } \\
\text { size }\end{array}$ & $\begin{array}{l}\text { Structure } \\
\text { efficiency }\end{array}$ \\
\hline Observation & & 3091 & 3091 & 2369 \\
\hline Mean & & 0.218 & 0.577 & 12.375 \\
\hline Min & & 0 & 0 & 0 \\
\hline $\operatorname{Max}$ & & 17.443 & 186.201 & 1168.224 \\
\hline \multirow{5}{*}{ Standard Deviation } & overall & 0.615 & 30.434 & 370.889 \\
\hline & between & 0.116 & 0.366 & 50.977 \\
\hline & Within & 0.604 & 30.415 & 370.434 \\
\hline & & \multicolumn{3}{|c|}{ Correlation coefficients } \\
\hline & & $\begin{array}{c}\text { Structure } \\
\text { activity }\end{array}$ & $\begin{array}{l}\text { Structure } \\
\text { size }\end{array}$ & $\begin{array}{l}\text { Structure } \\
\text { efficiency }\end{array}$ \\
\hline Structure-activity & & 1.0000 & - & - \\
\hline Structure-size & & $0.6308^{*}$ & 1.0000 & - \\
\hline Structure-efficiency & & $0.6496^{*}$ & $0.3761^{*}$ & 1.0000 \\
\hline Exports/GDP & & $0.1149^{*}$ & $0.2270^{*}$ & $0.1210^{*}$ \\
\hline Imports/GDP & & -0.0430 & 0.0247 & -0.0622 \\
\hline FDI/GDP & & 0.0511 & $0.1282^{*}$ & -0.0070 \\
\hline Trade concentration index & & $-0.2800^{*}$ & $-0.2148^{*}$ & $-0.4055^{*}$ \\
\hline Trade diversification index & & $-0.4399^{*}$ & $-0.2523^{*}$ & $-0.6429^{*}$ \\
\hline MFN rate & & $-0.1583^{*}$ & $-0.1120^{*}$ & $-0.2151^{*}$ \\
\hline Actual economic flows index & & $0.1891^{*}$ & $0.3182^{*}$ & $0.2617^{*}$ \\
\hline Social globalization index & & $0.4497^{*}$ & $0.4060^{*}$ & $0.6456^{*}$ \\
\hline Political globalization index & & $0.4456^{*}$ & $0.4029^{*}$ & $0.5179 *$ \\
\hline KAOPEN index & & $0.2834^{*}$ & $0.3095^{*}$ & $0.4160^{*}$ \\
\hline GDP per capita & & $0.4500^{*}$ & $0.4118^{*}$ & $0.6459^{*}$ \\
\hline Growth rate & & 0.0073 & 0.0127 & $-0.1179^{*}$ \\
\hline GDPper $^{2}$ & & $0.4499^{*}$ & $0.4118^{*}$ & $0.6459^{*}$ \\
\hline Exchange rate difference & & $0.1516^{*}$ & $0.1488^{*}$ & $0.1772^{*}$ \\
\hline Population & & $0.3318^{*}$ & $0.2252^{*}$ & $0.2804^{*}$ \\
\hline Inflation & & $0.2825^{*}$ & $0.2660^{*}$ & $0.4986^{*}$ \\
\hline Area & & $0.1202^{*}$ & 0.0572 & 0.0606 \\
\hline Initial level of banking development & & $0.4020^{*}$ & $0.2938^{*}$ & $0.6147^{*}$ \\
\hline Initial level of market development & & $0.4303^{*}$ & $0.4099^{*}$ & $0.4859^{*}$ \\
\hline Government quality & & 0.0072 & 0.0034 & 0.0184 \\
\hline Political stability index & & $0.3880^{*}$ & $0.2590^{*}$ & $0.4240^{*}$ \\
\hline Constraints on the executive & & $0.1231^{*}$ & $0.1173^{*}$ & $0.1648^{*}$ \\
\hline Democracy index & & $0.1374^{*}$ & $0.1698^{*}$ & $0.2319^{*}$ \\
\hline
\end{tabular}

Note: * indicates statistical significance at least the $10 \%$ level. 
Table 2: OLS estimator's results - Full sample

\begin{tabular}{|c|c|c|c|c|c|c|c|}
\hline \multirow[b]{2}{*}{ Independent variables } & \multicolumn{2}{|c|}{ Structure-activity } & \multicolumn{3}{|c|}{ Structure - size } & \multicolumn{2}{|c|}{ Structure-efficiency } \\
\hline & Coef. & $\begin{array}{l}\text { Standard } \\
\text { error }\end{array}$ & & Coef. & $\begin{array}{c}\text { Standard } \\
\text { error }\end{array}$ & Coef. & $\begin{array}{c}\text { Standard } \\
\text { error }\end{array}$ \\
\hline Exports/GDP & -0.124 & 0.139 & & $-0.194^{* *}$ & 0.094 & 0.454 & 0.347 \\
\hline Imports/GDP & -0.248 & 0.318 & & $-0.604^{* * *}$ & 0.167 & $0.924^{*}$ & 0.560 \\
\hline FDI/GDP & $0.045^{\star * *}$ & 0.018 & & $0.038^{* * *}$ & 0.012 & $0.027^{* *}$ & 0.015 \\
\hline Trade concentration index & -0.061 & 0.080 & & $-0.266^{* *}$ & 0.114 & -0.401 & 0.321 \\
\hline Trade diversification index & 0.027 & 0.204 & & 0.341 & 0.227 & 0.670 & 0.657 \\
\hline MFN & $-0.005^{\star *}$ & 0.002 & & $-0.003^{* * *}$ & 0.001 & $-0.009^{*}$ & 0.005 \\
\hline Actual economic flow index & 0.000 & 0.001 & & 0.001 & 0.001 & 0.006 & 0.005 \\
\hline Social global index & $0.006^{* * *}$ & 0.002 & & 0.003 & 0.002 & 0.011 & 0.007 \\
\hline Political globalization index & -0.001 & 0.001 & & 0.001 & 0.001 & -0.002 & 0.003 \\
\hline KAOPEN & -0.008 & 0.010 & & $0.027^{* *}$ & 0.013 & 0.006 & 0.027 \\
\hline GDP per capita & $59.128^{* * *}$ & 21.548 & & $59.358^{* *}$ & 28.944 & $262.791^{* * *}$ & 112.722 \\
\hline GDPper ${ }^{2}$ & $-29.519^{* * *}$ & 10.752 & & $-29.675^{* *}$ & 14.453 & $-131.197^{* *}$ & 56.244 \\
\hline Growth rate & $0.034^{* * *}$ & 0.007 & & $0.039 * *$ & 0.014 & $0.064^{* *}$ & 0.027 \\
\hline Population & $0.096^{* * *}$ & 0.022 & & $0.132^{* * *}$ & 0.025 & $0.341^{* * *}$ & 0.088 \\
\hline Inflation & 0.011 & 0.032 & & 0.018 & 0.051 & 0.032 & 0.114 \\
\hline Area & 0.014 & 0.012 & & -0.008 & 0.017 & 0.018 & 0.056 \\
\hline Exchange rate difference & $-0.013^{* * *}$ & 0.004 & & 0.001 & 0.007 & -0.009 & 0.014 \\
\hline Government quality & 0.000 & 0.000 & & $0.000^{* *}$ & 0.000 & $-0.001^{* *}$ & 0.000 \\
\hline Political Durability & 0.001 & 0.001 & & 0.000 & 0.001 & 0.000 & 0.002 \\
\hline Constraints on the executive & 0.000 & 0.000 & & -0.001 & 0.001 & 0.001 & 0.001 \\
\hline Democracy index & -0.003 & 0.004 & & 0.004 & 0.003 & -0.007 & 0.011 \\
\hline Banking development & -0.097 & 0.134 & & -0.243 & 0.169 & $1.127^{* * *}$ & 0.531 \\
\hline Market development & 0.120 & 0.144 & & $0.486^{* *}$ & 0.152 & 0.704 & 0.502 \\
\hline EAP region & -0.087 & 0.129 & & -0.079 & 0.101 & 0.489 & 0.463 \\
\hline EECA region & 0.132 & 0.184 & & 0.002 & 0.109 & 0.391 & 0.569 \\
\hline MENA region & -0.123 & 0.124 & & 0.090 & 0.096 & 0.352 & 0.398 \\
\hline SA region & 0.187 & 0.147 & & -0.002 & 0.059 & 0.430 & 0.288 \\
\hline WE region & -0.196 & 0.156 & & -0.131 & 0.138 & 0.193 & 0.558 \\
\hline NA region & $-0.294^{* *}$ & 0.158 & & $-0.365^{\star *}$ & 0.139 & -0.306 & 0.538 \\
\hline SSA region & -0.131 & 0.121 & & 0.035 & 0.061 & -0.174 & 0.281 \\
\hline LAC region & -0.214 & 0.131 & & -0.009 & 0.083 & -0.320 & 0.334 \\
\hline Low-income country & 0.010 & 0.181 & & -0.377 & 0.251 & -0.911 & 0.810 \\
\hline LMI country & -0.041 & 0.144 & & -0.128 & 0.205 & -1.033 & 0.675 \\
\hline UMI country & -0.056 & 0.121 & & -0.037 & 0.174 & -0.364 & 0.534 \\
\hline OECD & $-0.251^{* *}$ & 0.123 & & $-0.215^{*}$ & 0.118 & -0.624 & 0.499 \\
\hline Non-OECD & - & - & - & & - & - & - \\
\hline Leg_british & $-0.279 * * *$ & 0.129 & & -0.129 & 0.115 & $-0.703^{* * *}$ & 0.399 \\
\hline Leg_french & $-0.220 * *$ & 0.129 & & $-0.298^{* *}$ & 0.108 & -0.846 & 0.360 \\
\hline Leg_socialist & $-0.641^{* * *}$ & 0.215 & & $-0.352^{* *}$ & 0.168 & $-0.682^{* *}$ & 0.625 \\
\hline Leg_german & -0.176 & 0.159 & & $-0.384^{* *}$ & 0.146 & $-0.884^{* *}$ & 0.442 \\
\hline Leg_scandivanian & - & - & - & & - & - & - \\
\hline Constant & $-2.310^{* * *}$ & 0.741 & & $-2.155^{* * *}$ & 0.791 & $-7.658^{* *}$ & 3.369 \\
\hline
\end{tabular}

Note: ${ }^{*}(* * * *)$ indicate statistical significance at the $10 \%(5 \% ; 1 \%)$ level, respectively. 
Table 3.1: OLS estimator's results - Low-income countries sample

\begin{tabular}{|c|c|c|c|c|c|c|}
\hline \multirow[b]{2}{*}{ Independent variables } & \multicolumn{2}{|c|}{ Structure-activity } & \multicolumn{2}{|c|}{ Structure - size } & \multicolumn{2}{|c|}{ Structure-efficiency } \\
\hline & Coef. & $\begin{array}{l}\text { Standard } \\
\text { error }\end{array}$ & Coef. & $\begin{array}{l}\text { Standard } \\
\text { error }\end{array}$ & Coef. & $\begin{array}{l}\text { Standard } \\
\text { error }\end{array}$ \\
\hline Exports/GDP & -0.037 & 0.060 & -0.166 & 0.310 & -0.964 & 1.174 \\
\hline Imports/GDP & -0.100 & 0.148 & -0.472 & 0.836 & -2.142 & 2.511 \\
\hline FDI/GDP & -0.001 & 0.005 & 0.028 & 0.021 & 0.034 & 0.046 \\
\hline Trade concentration index & 0.033 & 0.027 & 0.022 & 0.115 & 0.024 & 0.130 \\
\hline Trade diversification index & -0.065 & 0.074 & -0.506 & 0.369 & -0.432 & 0.361 \\
\hline MFN & $-0.002^{* *}$ & 0.001 & -0.003 & 0.002 & $-0.020^{\star * *}$ & 0.003 \\
\hline Actual economic flow index & 0.000 & 0.001 & -0.005 & 0.002 & 0.000 & 0.004 \\
\hline Social global index & 0.001 & 0.001 & 0.007 & 0.005 & 0.011 & 0.009 \\
\hline Political globalization index & 0.001 & 0.000 & 0.002 & 0.001 & 0.001 & 0.003 \\
\hline KAOPEN & -0.002 & 0.003 & $-0.044^{*}$ & 0.025 & 0.013 & 0.041 \\
\hline GDP per capita & 21.250 & 16.974 & -37.730 & 55.834 & -9.681 & 194.635 \\
\hline GDPper $^{2}$ & -10.577 & 8.446 & 18.720 & 27.777 & 4.681 & 96.815 \\
\hline Growth rate & 0.002 & 0.003 & 0.014 & 0.011 & 0.025 & 0.030 \\
\hline Population & 0.011 & 0.016 & 0.016 & 0.057 & -0.121 & 0.097 \\
\hline Inflation & 0.028 & 0.022 & 0.037 & 0.054 & -0.025 & 0.070 \\
\hline Area & 0.001 & 0.006 & 0.011 & 0.023 & 0.018 & 0.049 \\
\hline Exchange rate difference & -0.004 & 0.004 & 0.003 & 0.010 & -0.001 & 0.010 \\
\hline Government quality & $-0.019 * *$ & 0.009 & $-0.057^{*}$ & 0.036 & 0.125 & 0.119 \\
\hline Political Durability & -0.001 & 0.001 & 0.001 & 0.002 & 0.011 & 0.008 \\
\hline Constraints on the executive & 0.000 & 0.000 & -0.001 & 0.000 & -0.001 & 0.001 \\
\hline Democracy index & 0.000 & 0.001 & $0.007^{* *}$ & 0.003 & 0.011 & 0.011 \\
\hline Banking development & 0.028 & 0.102 & 0.233 & 0.506 & -0.594 & 0.537 \\
\hline Market development & 0.394 & 0.436 & $5.288^{* *}$ & 2.365 & 15.109 & 3.850 \\
\hline EAP region & - & - & - & - & - & - \\
\hline EECA region & $0.211^{* * *}$ & 0.048 & 0.054 & 0.203 & 2.736 & 0.400 \\
\hline MENA region & - & - & - & - & - & - \\
\hline SA region & $0.074^{* * *}$ & 0.025 & $-0.218^{* *}$ & 0.113 & $2.787^{* * *}$ & 0.291 \\
\hline WE region & - & - & - & - & - & - \\
\hline NA region & - & - & - & - & - & - \\
\hline SSA region & 0.034 & 0.025 & -0.076 & 0.099 & -0.059 & 0.157 \\
\hline LAC region & - & - & - & - & - & - \\
\hline Leg_british & 0.012 & 0.007 & $0.244^{* * *}$ & 0.030 & 0.154 & 0.110 \\
\hline Leg_french & - & - & - & - & - & - \\
\hline Leg_socialist & - & - & - & - & - & - \\
\hline Leg_german & - & - & - & - & - & - \\
\hline Leg_scandivanian & - & - & - & - & - & - \\
\hline Constant & $-0.885^{*}$ & 0.535 & 1.213 & 1.744 & 4.772 & 7.788 \\
\hline
\end{tabular}

Note: $\left.{ }^{*} * * * * *\right)$ indicate statistical significance at the $10 \%(5 \% ; 1 \%)$ level, respectively. 
Table 3.2: OLS estimator's results - LMI countries sample

\begin{tabular}{|c|c|c|c|c|c|c|}
\hline \multirow[b]{2}{*}{ Independent variables } & \multicolumn{2}{|c|}{ Structure-activity } & \multicolumn{2}{|c|}{ Structure - size } & \multicolumn{2}{|c|}{ Structure-efficiency } \\
\hline & Coef. & $\begin{array}{l}\text { Standard } \\
\text { error }\end{array}$ & Coef. & $\begin{array}{l}\text { Standard } \\
\text { error }\end{array}$ & Coef. & $\begin{array}{l}\text { Standard } \\
\text { error }\end{array}$ \\
\hline Exports/GDP & 0.127 & 0.138 & 0.022 & 0.297 & 0.149 & 0.212 \\
\hline Imports/GDP & 0.351 & 0.238 & -0.631 & 0.490 & 0.146 & 0.302 \\
\hline FDI/GDP & 0.017 & 0.013 & -0.031 & 0.040 & -0.001 & 0.031 \\
\hline Trade concentration index & 0.130 & 0.158 & -0.319 & 0.261 & 0.278 & 0.233 \\
\hline Trade diversification index & $-0.621^{* * *}$ & 0.294 & -0.717 & 0.416 & -0.750 & 0.559 \\
\hline MFN & $-0.008^{* * *}$ & 0.003 & $-0.006^{* * *}$ & 0.002 & $-0.011^{* * *}$ & 0.004 \\
\hline Actual economic flow index & -0.001 & 0.002 & $0.006^{* *}$ & 0.003 & $-0.005^{*}$ & 0.003 \\
\hline Social global index & $0.008^{\star * *}$ & 0.003 & -0.001 & 0.004 & $0.018^{\star *}$ & 0.008 \\
\hline Political globalization index & $0.003^{* * *}$ & 0.001 & 0.001 & 0.002 & 0.003 & 0.002 \\
\hline KAOPEN & $-0.021^{*}$ & 0.013 & $0.061^{* * *}$ & 0.018 & 0.011 & 0.020 \\
\hline GDP per capita & $1.021^{* * *}$ & 0.076 & $1.010^{* * *}$ & 0.083 & $0.293^{* *}$ & 0.124 \\
\hline GDPper $^{2}$ & $-2.302^{* *}$ & 1.116 & $-2.742^{* *}$ & 1.386 & $-3.943^{* *}$ & 1.755 \\
\hline Growth rate & $0.023^{*}$ & 0.015 & $0.140^{\star *}$ & 0.053 & $0.110^{* * *}$ & 0.026 \\
\hline Population & $0.059 * * *$ & 0.022 & 0.035 & 0.042 & $0.103^{* * *}$ & 0.029 \\
\hline Inflation & 0.032 & 0.034 & 0.103 & 0.091 & -0.004 & 0.060 \\
\hline Area & $0.060^{* * *}$ & 0.023 & $0.046^{* *}$ & 0.023 & $0.082^{* * *}$ & 0.022 \\
\hline Exchange rate difference & 0.004 & 0.005 & 0.004 & 0.016 & -0.007 & 0.009 \\
\hline Government quality & 0.000 & 0.000 & 0.000 & 0.000 & 0.000 & 0.000 \\
\hline Political Durability & $-0.005^{\star * *}$ & 0.002 & -0.001 & 0.002 & $-0.013^{* * *}$ & 0.003 \\
\hline Constraints on the executive & 0.001 & 0.001 & -0.001 & 0.001 & 0.002 & 0.001 \\
\hline Democracy index & -0.010 & 0.008 & 0.005 & 0.004 & $-0.026^{*}$ & 0.015 \\
\hline Banking development & $0.554^{* *}$ & 0.228 & $0.635^{*}$ & 0.382 & $0.835^{* *}$ & 0.437 \\
\hline Market development & $1.251^{* * *}$ & 0.404 & $4.369^{* * *}$ & 0.664 & $1.465^{*}$ & 0.921 \\
\hline EAP region & -0.075 & 0.071 & -0.194 & 0.102 & -0.053 & 0.209 \\
\hline EECA region & -0.057 & 0.116 & $0.286^{* *}$ & 0.137 & 0.078 & 0.261 \\
\hline MENA region & 0.084 & 0.067 & $0.331^{* *}$ & 0.127 & -0.010 & 0.206 \\
\hline SA region & $0.272^{* *}$ & 0.127 & -0.088 & 0.069 & $0.641^{* * *}$ & 0.203 \\
\hline WE region & - & - & - & - & - & - \\
\hline NA region & - & - & - & - & - & - \\
\hline SSA region & -0.088 & 0.082 & -0.001 & 0.077 & $-0.405^{*}$ & 0.216 \\
\hline LAC region & -0.019 & 0.071 & -0.025 & 0.094 & -0.083 & 0.215 \\
\hline Leg_british & $0.206^{* *}$ & 0.081 & $0.443^{* * *}$ & 0.069 & $0.251^{* *}$ & 0.111 \\
\hline Leg_french & - & - & - & - & - & - \\
\hline Leg_socialist & - & - & - & - & - & - \\
\hline Leg_german & - & - & - & - & - & - \\
\hline Leg_scandivanian & - & - & - & - & - & - \\
\hline Constant & -0.936 & 1.004 & -1.174 & 1.108 & 0.407 & 1.554 \\
\hline
\end{tabular}

Note: ${ }^{*}\left({ }^{* *} ; * *\right)$ indicate statistical significance at the $10 \%(5 \% ; 1 \%)$ level, respectively. 
Table 3.3: OLS estimator's results - UMI countries sample

\begin{tabular}{|c|c|c|c|c|c|c|}
\hline \multirow[b]{2}{*}{ Independent variables } & \multicolumn{2}{|c|}{ Structure-activity } & \multicolumn{2}{|c|}{ Structure - size } & \multicolumn{2}{|c|}{ Structure-efficiency } \\
\hline & Coef. & $\begin{array}{c}\text { Standard } \\
\text { error }\end{array}$ & Coef. & $\begin{array}{c}\text { Standard } \\
\text { error }\end{array}$ & Coef. & $\begin{array}{c}\text { Standard } \\
\text { error }\end{array}$ \\
\hline Exports/GDP & -0.396 & 0.306 & $-0.820^{*}$ & 0.437 & $2.870^{* *}$ & 1.361 \\
\hline Imports/GDP & -0.236 & 0.250 & $-0.807^{* *}$ & 0.391 & -1.174 & 0.990 \\
\hline FDI/GDP & $0.031^{* *}$ & 0.018 & $0.051^{* * *}$ & 0.021 & $0.160 * * *$ & 0.060 \\
\hline Trade concentration index & $-0.292^{* *}$ & 0.103 & $-0.479 * * *$ & 0.220 & 0.582 & 0.567 \\
\hline Trade diversification index & 0.220 & 0.244 & $0.573^{*}$ & 0.358 & $-1.869^{* *}$ & 0.871 \\
\hline MFN & -0.001 & 0.002 & 0.001 & 0.002 & 0.003 & 0.006 \\
\hline Actual economic flow index & 0.000 & 0.001 & 0.001 & 0.002 & $0.018^{\star * *}$ & 0.006 \\
\hline Social global index & 0.000 & 0.002 & 0.002 & 0.003 & $0.014^{*}$ & 0.008 \\
\hline Political globalization index & 0.001 & 0.001 & 0.000 & 0.001 & $0.010^{* *}$ & 0.005 \\
\hline KAOPEN & -0.001 & 0.009 & $0.033^{* *}$ & 0.019 & 0.021 & 0.033 \\
\hline GDP per capita & $1.057^{* * *}$ & 0.044 & $1.004^{* * *}$ & 0.098 & $1.089^{* * *}$ & 0.266 \\
\hline GDPper $^{2}$ & $-3.302^{* *}$ & 1.094 & $-2.502^{* *}$ & 1.004 & $-2.854^{* *}$ & 1.004 \\
\hline Growth rate & $0.040^{* * *}$ & 0.012 & $0.042^{* *}$ & 0.021 & $0.133^{* *}$ & 0.053 \\
\hline Population & $0.100^{* * *}$ & 0.024 & $0.139 * *$ & 0.056 & $0.270^{* *}$ & 0.141 \\
\hline Inflation & 0.031 & 0.046 & -0.041 & 0.079 & -0.077 & 0.211 \\
\hline Area & 0.023 & 0.017 & 0.039 & 0.041 & 0.028 & 0.100 \\
\hline Exchange rate difference & -0.002 & 0.005 & -0.001 & 0.006 & 0.019 & 0.012 \\
\hline Government quality & 0.039 & 0.029 & $0.092^{* *}$ & 0.049 & $0.410^{* *}$ & 0.148 \\
\hline Political Durability & 0.000 & 0.001 & 0.001 & 0.002 & -0.003 & 0.005 \\
\hline Constraints on the executive & 0.001 & 0.000 & 0.001 & 0.001 & 0.003 & 0.002 \\
\hline Democracy index & -0.003 & 0.004 & 0.008 & 0.005 & -0.003 & 0.018 \\
\hline Banking development & $-0.373^{* *}$ & 0.136 & $-0.628^{* * *}$ & 0.284 & 0.543 & 0.679 \\
\hline Market development & $0.224^{* *}$ & 0.161 & $0.811^{* *}$ & 0.399 & 0.247 & 0.718 \\
\hline EAP region & $0.333^{* * *}$ & 0.099 & -0.233 & 0.228 & $2.818^{* * *}$ & 0.617 \\
\hline EECA region & $0.448^{* * *}$ & 0.054 & 0.141 & 0.119 & $1.830^{* * *}$ & 0.275 \\
\hline MENA region & 0.078 & 0.070 & 0.138 & 0.124 & $0.617^{*}$ & 0.354 \\
\hline SA region & - & - & - & - & - & - \\
\hline WE region & - & - & - & - & - & - \\
\hline NA region & - & - & - & - & - & - \\
\hline SSA region & $0.303^{* * *}$ & 0.054 & $0.268^{* *}$ & 0.112 & $1.319^{* *}$ & 0.429 \\
\hline LAC region & - & - & - & - & - & - \\
\hline Leg_british & $0.179^{* *}$ & 0.095 & -0.043 & 0.183 & 0.760 & 0.489 \\
\hline Leg_french & $0.430 * * *$ & 0.086 & 0.119 & 0.145 & $1.680^{* * *}$ & 0.325 \\
\hline Leg_socialist & - & - & - & - & - & - \\
\hline Leg_german & - & - & - & - & - & - \\
\hline Leg_scandivanian & - & - & - & - & - & - \\
\hline Constant & $-3.463^{* * *}$ & 0.768 & $-3.259^{* * *}$ & 1.077 & -4.545 & 3.227 \\
\hline
\end{tabular}

Note: ${ }^{*}(* * ; * *)$ indicate statistical significance at the $10 \%(5 \% ; 1 \%)$ level, respectively. 
Table 3.4: OLS estimator's results - High-income countries sample

\begin{tabular}{|c|c|c|c|c|c|c|}
\hline \multirow[b]{2}{*}{ Independent variables } & \multicolumn{2}{|c|}{ Structure-activity } & \multicolumn{2}{|c|}{ Structure - size } & \multicolumn{2}{|c|}{ Structure-efficiency } \\
\hline & Coef. & $\begin{array}{c}\text { Standard } \\
\text { error }\end{array}$ & Coef. & $\begin{array}{c}\text { Standard } \\
\text { error }\end{array}$ & Coef. & $\begin{array}{c}\text { Standard } \\
\text { error }\end{array}$ \\
\hline Exports/GDP & $-1.198^{* * *}$ & 0.288 & $-0.734^{* * *}$ & 0.182 & -5.676 & 3.484 \\
\hline Imports/GDP & $-1.379^{* *}$ & 0.650 & $-1.196^{* * *}$ & 0.296 & -3.795 & 3.372 \\
\hline FDI/GDP & $0.056^{* *}$ & 0.026 & $0.042^{* * *}$ & 0.016 & -0.022 & 0.062 \\
\hline Trade concentration index & -0.433 & 0.408 & $-0.851^{* *}$ & 0.304 & $3.077^{* * *}$ & 0.930 \\
\hline Trade diversification index & 0.403 & 0.521 & $1.020^{* * *}$ & 0.405 & 1.248 & 1.267 \\
\hline MFN & -0.002 & 0.010 & 0.004 & 0.007 & 0.026 & 0.021 \\
\hline Actual economic flow index & 0.002 & 0.002 & -0.001 & 0.002 & -0.007 & 0.010 \\
\hline Social global index & 0.004 & 0.003 & $0.007^{* * *}$ & 0.002 & $0.016^{*}$ & 0.009 \\
\hline Political globalization index & $-0.009^{* *}$ & 0.004 & -0.002 & 0.003 & -0.011 & 0.008 \\
\hline KAOPEN & $-0.059^{* * *}$ & 0.028 & 0.006 & 0.018 & -0.039 & 0.049 \\
\hline GDP per capita & $0.615^{* * *}$ & 0.145 & $0.602^{* * *}$ & 0.096 & $0.623^{* *}$ & 0.304 \\
\hline GDPper ${ }^{2}$ & $-2.705^{* *}$ & 1.600 & $-2.548^{*}$ & 1.332 & $-2.002^{* *}$ & 0.910 \\
\hline Growth rate & $0.070^{* * *}$ & 0.015 & $0.093^{* * *}$ & 0.019 & $0.132^{* *}$ & 0.057 \\
\hline Population & $0.287^{* * *}$ & 0.055 & $0.176^{* * *}$ & 0.038 & $0.675^{* * *}$ & 0.084 \\
\hline Inflation & $-0.271^{\star *}$ & 0.147 & -0.142 & 0.123 & $-0.630^{*}$ & 0.355 \\
\hline Area & $0.055^{\star *}$ & 0.026 & 0.010 & 0.024 & 0.040 & 0.062 \\
\hline Exchange rate difference & -0.008 & 0.012 & $0.070^{* * *}$ & 0.008 & -0.104 & 0.061 \\
\hline Government quality & -0.065 & 0.079 & -0.011 & 0.053 & -0.224 & 0.246 \\
\hline Political Durability & $0.005^{* * *}$ & 0.001 & $0.002^{*}$ & 0.001 & 0.002 & 0.003 \\
\hline Constraints on the executive & 0.111 & 0.079 & -0.050 & 0.057 & 0.450 & 0.247 \\
\hline Democracy index & -0.017 & 0.025 & 0.015 & 0.021 & -0.060 & 0.069 \\
\hline Banking development & $0.887^{* * *}$ & 0.247 & 0.342 & 0.246 & $1.827^{* *}$ & 0.762 \\
\hline Market development & $-0.575^{* *}$ & 0.252 & 0.137 & 0.214 & $-0.997^{*}$ & 0.516 \\
\hline EAP region & 0.348 & 0.261 & $-0.590^{* *}$ & 0.219 & $2.474^{* * *}$ & 0.539 \\
\hline EECA region & $-0.790^{* * *}$ & 0.232 & $-0.959 * * *$ & 0.206 & -0.256 & 0.597 \\
\hline MENA region & 0.346 & 0.203 & -0.232 & 0.165 & $0.969^{* *}$ & 0.406 \\
\hline SA region & - & - & - & - & - & - \\
\hline WE region & -0.050 & 0.199 & $-0.690^{* * *}$ & 0.157 & $1.208^{* *}$ & 0.442 \\
\hline NA region & -0.161 & 0.266 & $-0.808^{* * *}$ & 0.222 & $1.227^{* *}$ & 0.596 \\
\hline SSA region & -0.425 & 0.351 & $-0.601^{* * *}$ & 0.237 & - & - \\
\hline LAC region & - & - & - & - & - & - \\
\hline Leg_british & $-0.937^{* * *}$ & 0.152 & $-0.427^{* * *}$ & 0.154 & $-1.556^{* * *}$ & 0.416 \\
\hline Leg_french & $-0.492^{* * *}$ & 0.098 & $-0.345^{* * *}$ & 0.100 & -0.796 & 0.305 \\
\hline Leg_socialist & - & - & - & - & - & - \\
\hline Leg_german & $-0.622^{* * *}$ & 0.131 & $-0.474^{* * *}$ & 0.136 & -1.396 & 0.305 \\
\hline Leg_scandivanian & - & - & - & - & - & - \\
\hline OECD country & $-0.323^{* *}$ & 0.160 & -0.177 & 0.110 & 0.225 & 0.413 \\
\hline Constant & $-6.018^{* * *}$ & 1.790 & $-3.455^{\star * *}$ & 1.238 & -20.524 & 4.572 \\
\hline
\end{tabular}

Note: ${ }^{*}(* * ; * *)$ indicate statistical significance at the $10 \%(5 \% ; 1 \%)$ level, respectively. 


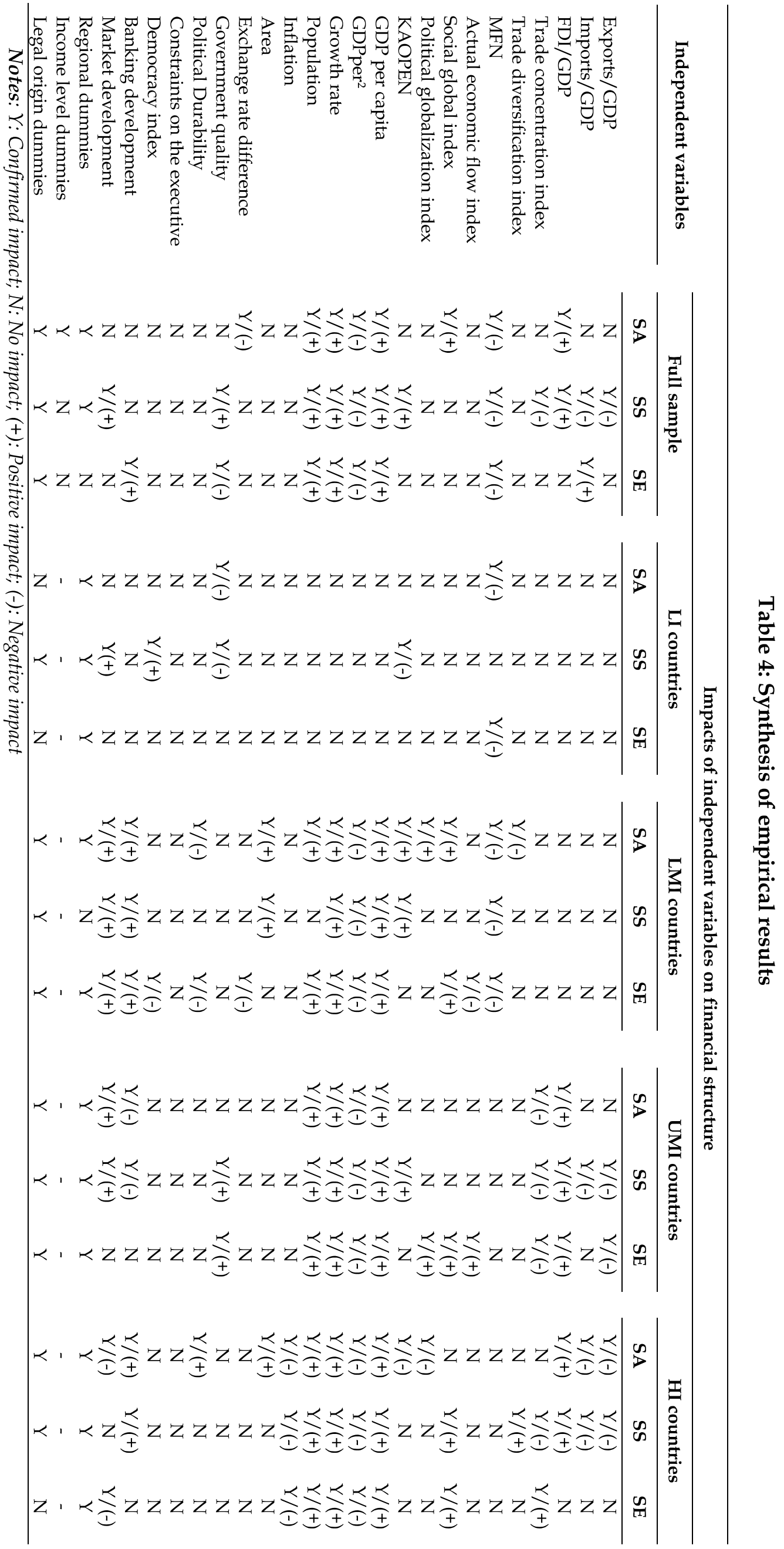


Table 5: OLS estimator's results - Full sample (Low-income countries excluded)

\begin{tabular}{|c|c|c|c|c|c|c|}
\hline \multirow[b]{2}{*}{ Independent variables } & \multicolumn{2}{|c|}{ Structure-activity } & \multicolumn{2}{|c|}{ Structure - size } & \multicolumn{2}{|c|}{ Structure-efficiency } \\
\hline & Coef. & $\begin{array}{c}\text { Standard } \\
\text { error }\end{array}$ & Coef. & $\begin{array}{c}\begin{array}{c}\text { Standard } \\
\text { error }\end{array} \\
\end{array}$ & Coef. & $\begin{array}{c}\text { Standard } \\
\text { error }\end{array}$ \\
\hline Exports/GDP & -0.247 & 0.167 & $-0.211^{*}$ & 0.115 & 0.457 & 0.451 \\
\hline Imports/GDP & -0.356 & 0.333 & $-0.624^{\star * *}$ & 0.170 & $-1.009^{*}$ & 0.601 \\
\hline FDI/GDP & $0.055^{\star \star *}$ & 0.019 & $0.041^{* * *}$ & 0.014 & $0.628^{*}$ & 0.037 \\
\hline Trade concentration index & $-0.203^{*}$ & 0.119 & $-0.364^{* *}$ & 0.152 & -0.500 & 0.459 \\
\hline Trade diversification index & 0.272 & 0.223 & $0.557^{* *}$ & 0.269 & 0.617 & 0.688 \\
\hline MFN & $-0.007^{* *}$ & 0.003 & $-0.004^{* *}$ & 0.002 & $-0.010^{* *}$ & 0.005 \\
\hline Actual economic flow index & 0.000 & 0.001 & 0.001 & 0.001 & 0.006 & 0.005 \\
\hline Social global index & $0.006^{\star * *}$ & 0.002 & 0.003 & 0.002 & 0.012 & 0.007 \\
\hline Political globalization index & -0.001 & 0.001 & 0.001 & 0.001 & -0.002 & 0.003 \\
\hline KAOPEN & -0.014 & 0.011 & $0.024^{* *}$ & 0.011 & -0.005 & 0.028 \\
\hline GDP per capita & $105.687^{* *}$ & 51.212 & $213.054^{* *}$ & 106.164 & $498.811^{*}$ & 283.786 \\
\hline GDPper $^{2}$ & $-72.787^{* *}$ & 35.585 & $-106.498^{* *}$ & 53.060 & $-249.097^{* *}$ & 121.749 \\
\hline Growth rate & $0.045^{* * *}$ & 0.008 & $0.047^{* *}$ & 0.017 & $0.079 * *$ & 0.030 \\
\hline Population & $0.132^{* * *}$ & 0.025 & $0.154^{* * *}$ & 0.029 & $0.386^{* * *}$ & 0.087 \\
\hline Inflation & $0.007^{* *}$ & 0.039 & 0.004 & 0.046 & 0.000 & 0.129 \\
\hline Area & 0.009 & 0.015 & -0.004 & 0.020 & 0.015 & 0.061 \\
\hline Exchange rate difference & $-0.012^{* *}$ & 0.005 & 0.007 & 0.009 & -0.005 & 0.015 \\
\hline Government quality & 0.000 & 0.000 & $0.000^{*}$ & 0.000 & $0.000^{*}$ & 0.000 \\
\hline Political Durability & 0.001 & 0.001 & 0.000 & 0.001 & -0.003 & 0.003 \\
\hline Constraints on the executive & 0.000 & 0.000 & -0.001 & 0.001 & 0.001 & 0.001 \\
\hline Democracy index & -0.005 & 0.006 & $0.009 * *$ & 0.004 & -0.019 & 0.017 \\
\hline Banking development & -0.094 & 0.145 & -0.264 & 0.182 & $1.226^{* *}$ & 0.520 \\
\hline Market development & 0.075 & 0.139 & $0.475^{\star *}$ & 0.155 & 0.348 & 0.475 \\
\hline EAP region & -0.149 & 0.134 & -0.060 & 0.093 & 0.445 & 0.392 \\
\hline EECA region & 0.052 & 0.178 & -0.032 & 0.094 & 0.241 & 0.507 \\
\hline MENA region & -0.184 & 0.138 & 0.144 & 0.109 & 0.099 & 0.378 \\
\hline SA region & 0.220 & 0.179 & 0.036 & 0.050 & $0.271^{*}$ & 0.145 \\
\hline WE region & -0.245 & 0.155 & -0.106 & 0.131 & -0.024 & 0.507 \\
\hline NA region & $-0.318^{* *}$ & 0.152 & $-0.336^{* *}$ & 0.139 & -0.315 & 0.458 \\
\hline SSA region & -0.139 & 0.120 & 0.060 & 0.062 & 0.100 & 0.180 \\
\hline LAC region & $-0.260^{* *}$ & 0.131 & -0.040 & 0.097 & -0.428 & 0.253 \\
\hline LMI country & 0.054 & 0.076 & $0.363^{\star *}$ & 0.115 & 0.321 & 0.241 \\
\hline UMI country & 0.074 & 0.114 & $0.487^{* * *}$ & 0.163 & $0.880^{* *}$ & 0.384 \\
\hline OECD & -0.085 & 0.212 & 0.242 & 0.226 & 0.656 & 0.689 \\
\hline Non-OECD & 0.140 & 0.181 & $0.515^{\star *}$ & 0.261 & 1.239 & 0.796 \\
\hline Leg_british & $-0.322^{* *}$ & 0.129 & -0.178 & 0.120 & $-0.829 * *$ & 0.404 \\
\hline Leg_french & $-0.246^{* *}$ & 0.124 & $-0.286^{* *}$ & 0.107 & $-0.855^{\star *}$ & 0.361 \\
\hline Leg_socialist & $-0.663^{* * *}$ & 0.208 & $-0.347^{* *}$ & 0.159 & -0.873 & 0.612 \\
\hline Leg_german & -0.207 & 0.160 & $-0.394^{* *}$ & 0.150 & $-1.044^{* *}$ & 0.402 \\
\hline Leg_scandivanian & - & - & - & - & - & - \\
\hline Constant & $-3.269^{* * *}$ & 0.772 & $-3.780 * * *$ & 0.959 & $-11.365^{\star * *}$ & 3.460 \\
\hline
\end{tabular}

Note: ${ }^{*}(* * ; * *)$ indicate statistical significance at the $10 \%(5 \% ; 1 \%)$ level, respectively. 
Table 6.1: IV estimator's results (Openness terms instrumented) - Full sample

\begin{tabular}{|c|c|c|c|c|c|c|}
\hline \multirow{2}{*}{ Independent variables } & \multicolumn{2}{|c|}{ Structure-activity } & \multicolumn{2}{|c|}{ Structure - size } & \multicolumn{2}{|c|}{ Structure - efficiency } \\
\hline & Coef. & Std. Err. & Coef. & Std. Err. & Coef. & Std. Err. \\
\hline Exports/GDP & $-0.623^{\star \star *}$ & 0.105 & $-0.046^{* * *}$ & 0.002 & -0.856 & 4.686 \\
\hline Imports/GDP & $-0.532^{\star * *}$ & 0.100 & $-0.444^{* * *}$ & 0.110 & -0.793 & 4.698 \\
\hline FDI/GDP & $0.159^{* * *}$ & 0.037 & $0.062^{* *}$ & 0.030 & $0.037^{* *}$ & 0.015 \\
\hline Actual economic flow index & 0.001 & 0.006 & -0.030 & 0.024 & -0.075 & 0.074 \\
\hline Social global index & $0.009^{* * *}$ & 0.002 & $0.019^{* * *}$ & 0.006 & $0.028^{* *}$ & 0.012 \\
\hline Political globalization index & 0.000 & 0.001 & 0.000 & 0.003 & -0.005 & 0.008 \\
\hline GDP per capita & $10.863^{* *}$ & 4.230 & $10.748^{* * *}$ & 3.004 & $9.903^{* *}$ & 3.854 \\
\hline GDPper $^{2}$ & $-5.483^{\star *}$ & 2.112 & $-6.240^{* * *}$ & 0.063 & $-4.373^{* *}$ & 0.140 \\
\hline Growth rate & $0.512^{\star \star *}$ & 0.036 & $0.274^{*}$ & 0.139 & $0.600^{* *}$ & 0.290 \\
\hline Population & $0.061^{* \star *}$ & 0.012 & 0.032 & 0.048 & $0.162^{*}$ & 0.089 \\
\hline Inflation & $-0.064^{*}$ & 0.036 & 0.203 & 0.141 & 0.306 & 0.438 \\
\hline Area & 0.019 & 0.013 & 0.016 & 0.053 & 0.167 & 0.142 \\
\hline Exchange rate difference & $-0.106^{* * *}$ & 0.007 & -0.029 & 0.028 & -0.064 & 0.050 \\
\hline Government quality & 0.000 & 0.000 & $0.000^{*}$ & 0.000 & $0.000^{*}$ & 0.000 \\
\hline Political Durability & 0.000 & 0.000 & -0.001 & 0.001 & -0.005 & 0.003 \\
\hline Contraints on the executive & 0.000 & 0.001 & -0.003 & 0.002 & -0.004 & 0.008 \\
\hline Democracy index & -0.003 & 0.002 & -0.007 & 0.008 & -0.022 & 0.024 \\
\hline Banking development & -0.067 & 0.071 & -0.130 & 0.278 & $1.883^{* *}$ & 0.780 \\
\hline Market development & $0.150^{* *}$ & 0.059 & $0.644^{* *}$ & 0.231 & 0.797 & 0.419 \\
\hline EAP region & 0.074 & 0.184 & -0.374 & 0.725 & 0.060 & 1.453 \\
\hline EECA region & 0.228 & 0.187 & -0.249 & 0.737 & 0.034 & 1.400 \\
\hline MENA region & -0.069 & 0.186 & -0.309 & 0.731 & -0.363 & 1.449 \\
\hline SA region & 0.258 & 0.185 & -0.300 & 0.726 & 0.271 & 1.402 \\
\hline WE region & -0.040 & 0.199 & -0.777 & 0.783 & -1.012 & 1.748 \\
\hline NA region & -0.176 & 0.194 & -0.655 & 0.764 & -0.622 & 1.537 \\
\hline SSA region & -0.056 & 0.187 & -0.492 & 0.734 & -0.835 & 1.440 \\
\hline LAC region & -0.268 & 0.204 & -0.864 & 0.803 & -1.741 & 1.656 \\
\hline Low-income country & 0.103 & 0.128 & -0.732 & 0.502 & -1.393 & 1.235 \\
\hline Lower middle-income country & 0.028 & 0.064 & -0.103 & 0.252 & -0.933 & 0.538 \\
\hline Upper middle-income country & 0.004 & 0.051 & 0.125 & 0.199 & -0.103 & 0.391 \\
\hline OECD & $-0.439^{* * *}$ & 0.059 & -0.136 & 0.231 & -0.049 & 0.770 \\
\hline Non-OECD & - & - & - & - & - & - \\
\hline Leg_british & $-0.249^{* * *}$ & 0.048 & -0.247 & 0.188 & $-1.058^{* *}$ & 0.533 \\
\hline Leg_french & $-0.195^{* * *}$ & 0.042 & $-0.311^{* *}$ & 0.164 & $-0.958^{* * *}$ & 0.373 \\
\hline Leg_socialist & $-0.718^{* * *}$ & 0.167 & $-1.477^{* * *}$ & 0.653 & $-2.982^{* *}$ & 1.981 \\
\hline Leg_german & -0.125 & 0.077 & 0.126 & 0.301 & -0.208 & 0.653 \\
\hline Leg_scandivanian & - & - & - & - & - & - \\
\hline Constant & $-2.949 * *$ & 0.959 & 3.263 & 3.764 & -3.767 & 9.076 \\
\hline Cragg-Donald Wald F-statistic & & 917 & 13.9 & & 14.67 & \\
\hline F-statistic & $(13$ & $.43)^{\mathrm{a}}$ & $(13.4$ & & $(13.4$ & \\
\hline P-value of Sargan test & {$[1.0$} & 000] & {$[1.0$} & & {$[1.00$} & \\
\hline
\end{tabular}

Notes: Values in brackets are P-values. Values in parentheses are robust standard errors. ${ }^{* * *}{ }^{* *}$. *: Significant at 1 percent, 5 percent, 10 percent level, respectively. ()a. Critical value of 15 percent maximal IV size proposed by Stock and Yogo (2002). 
Table 6.2: IV estimator's results (Financial development instrumented) - Full sample

\begin{tabular}{|c|c|c|c|c|c|c|}
\hline \multirow{2}{*}{ Independent variables } & \multicolumn{2}{|c|}{ Structure-activity } & \multicolumn{2}{|c|}{ Structure-size } & \multicolumn{2}{|c|}{ Structure-efficiency } \\
\hline & Coef. & Std. Err. & Coef. & Std. Err. & Coef. & Std. Err. \\
\hline Banking development & $-0.804^{\star \star *}$ & 0.173 & $-1.533^{\star * *}$ & 0.188 & $-1.178^{* * *}$ & 0.496 \\
\hline Market development & $1.704^{\star * *}$ & 0.159 & $1.183^{* * *}$ & 0.172 & $1.169^{* *}$ & 0.498 \\
\hline Exports/GDP & $-0.377^{* * *}$ & 0.093 & $-0.370^{* * *}$ & 0.102 & 0.000 & 0.387 \\
\hline Imports/GDP & $-0.483^{* * *}$ & 0.140 & $-0.983^{* * *}$ & 0.152 & 0.785 & 0.515 \\
\hline FDI/GDP & $0.030^{* *}$ & 0.011 & $0.044^{* * *}$ & 0.012 & $0.045^{\star * *}$ & 0.016 \\
\hline Trade concentration index & $-0.213^{* * *}$ & 0.063 & $-0.518^{* * *}$ & 0.069 & $-0.464^{* *}$ & 0.230 \\
\hline Trade diversification index & $0.367^{* *}$ & 0.110 & $0.694^{* * *}$ & 0.120 & 0.313 & 0.409 \\
\hline MFN & $-0.002^{* *}$ & 0.001 & $-0.002^{* *}$ & 0.001 & $-0.002^{* *}$ & 0.001 \\
\hline KAOPEN & -0.022 & 0.007 & 0.034 & 0.007 & 0.030 & 0.020 \\
\hline Actual economic flow index & -0.001 & 0.001 & 0.005 & 0.001 & -0.006 & 0.002 \\
\hline Social global index & $0.004^{* * *}$ & 0.001 & $0.006^{* * *}$ & 0.001 & $0.018^{* * *}$ & 0.003 \\
\hline Political globalization index & $0.003^{* * *}$ & 0.001 & 0.001 & 0.001 & 0.002 & 0.002 \\
\hline GDP per capita & $8.560^{* * *}$ & 1.022 & $8.009 * * *$ & 2.442 & $9.374^{* * *}$ & 1.204 \\
\hline GDPper ${ }^{2}$ & $-3.003^{* * *}$ & 0.011 & $-3.032^{* * *}$ & 0.012 & $-4.476^{* * *}$ & 0.040 \\
\hline Growth rate & $0.049^{* * *}$ & 0.010 & $0.033^{* * *}$ & 0.011 & $0.102^{* * *}$ & 0.033 \\
\hline Population & 0.017 & 0.011 & 0.114 & 0.012 & 0.237 & 0.036 \\
\hline Inflation & -0.047 & 0.029 & 0.143 & 0.031 & 0.153 & 0.098 \\
\hline Area & 0.025 & 0.007 & -0.009 & 0.007 & 0.106 & 0.021 \\
\hline Exchange rate difference & -0.001 & 0.004 & 0.005 & 0.004 & $-0.027^{* *}$ & 0.013 \\
\hline Government quality & 0.000 & 0.000 & 0.000 & 0.000 & 0.000 & 0.000 \\
\hline Political Durability & 0.000 & 0.000 & 0.000 & 0.000 & -0.003 & 0.001 \\
\hline Contraints on the executive & 0.000 & 0.001 & -0.001 & 0.001 & 0.000 & 0.002 \\
\hline Democracy index & $-0.002^{*}$ & 0.001 & $0.005^{\star * *}$ & 0.001 & 0.005 & 0.004 \\
\hline EAP region & 0.022 & 0.192 & -0.213 & 0.209 & 0.455 & 0.575 \\
\hline EECA region & -0.031 & 0.193 & -0.293 & 0.210 & -0.058 & 0.578 \\
\hline MENA region & 0.076 & 0.192 & -0.144 & 0.208 & 0.005 & 0.575 \\
\hline SA region & 0.168 & 0.194 & -0.188 & 0.211 & 0.202 & 0.581 \\
\hline WE region & 0.371 & 0.197 & -0.176 & 0.214 & 0.227 & 0.597 \\
\hline NA region & $-0.417^{* *}$ & 0.204 & $-0.479^{* *}$ & 0.221 & -0.482 & 0.619 \\
\hline SSA region & -0.119 & 0.191 & -0.253 & 0.208 & -0.533 & 0.572 \\
\hline LAC region & -0.020 & 0.193 & -0.306 & 0.209 & -0.800 & 0.578 \\
\hline Low-income country & 0.096 & 0.073 & -0.428 & 0.079 & -0.554 & 0.241 \\
\hline Lower middle-income country & -0.050 & 0.058 & -0.315 & 0.063 & -1.226 & 0.188 \\
\hline Upper middle-income country & 0.035 & 0.053 & -0.226 & 0.058 & -0.602 & 0.168 \\
\hline OECD & $-0.215^{\star * *}$ & 0.050 & $-0.427 * * *$ & 0.054 & $-0.734^{* * *}$ & 0.154 \\
\hline Leg_british & $-0.159 * *$ & 0.060 & -0.076 & 0.075 & -0.316 & 0.283 \\
\hline Leg_french & $-0.141^{* *}$ & 0.059 & $-0.216^{* *}$ & 0.072 & $-0.589^{* * *}$ & 0.246 \\
\hline Leg_socialist & -0.295 & 0.186 & $-0.464^{* *}$ & 0.230 & 0.479 & 0.819 \\
\hline Leg_german & $-0.221^{* * *}$ & 0.066 & $-0.159^{*}$ & 0.082 & $-1.759 * * *$ & 0.375 \\
\hline Constant & -1.418 & 0.398 & -2.312 & 0.433 & -8.165 & 1.356 \\
\hline Cragg-Donald Wald F-statistic & 49.1 & & 49. & & 37.7 & \\
\hline F-statistic & $(7.56$ & & (7.5 & $6)^{a}$ & (7.5 & $6)^{a}$ \\
\hline P-value of Sargan test & {$[1.00$} & & {$[1.0$} & 00] & {$[1.0$} & 00] \\
\hline
\end{tabular}

Notes: Values in brackets are P-values. Values in parentheses are robust standard errors. ***, ** *: Significant at 1 percent, 5 percent, 10 percent level, respectively. (), Critical value of 15 percent maximal IV size proposed by Stock and Yogo (2002). 


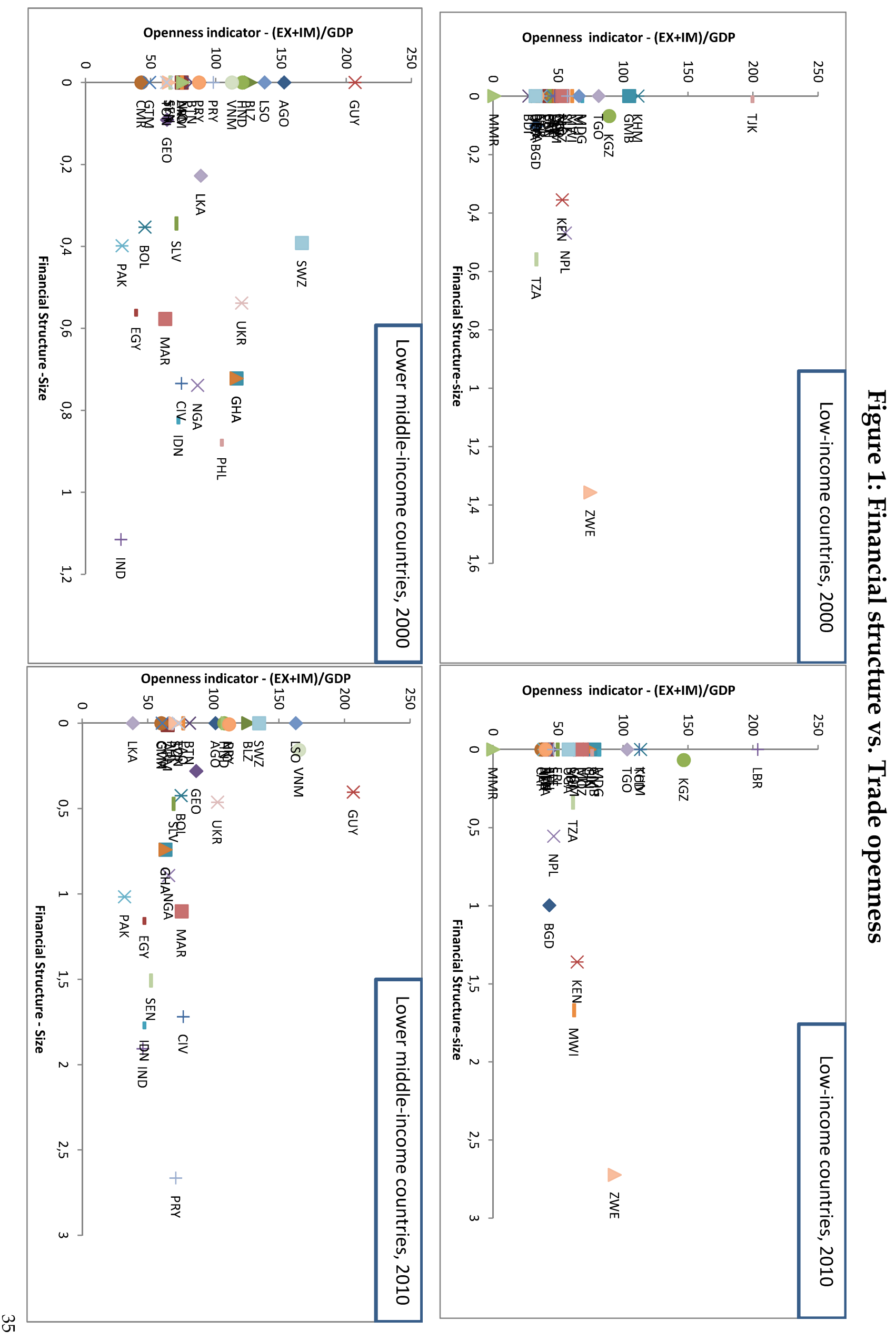




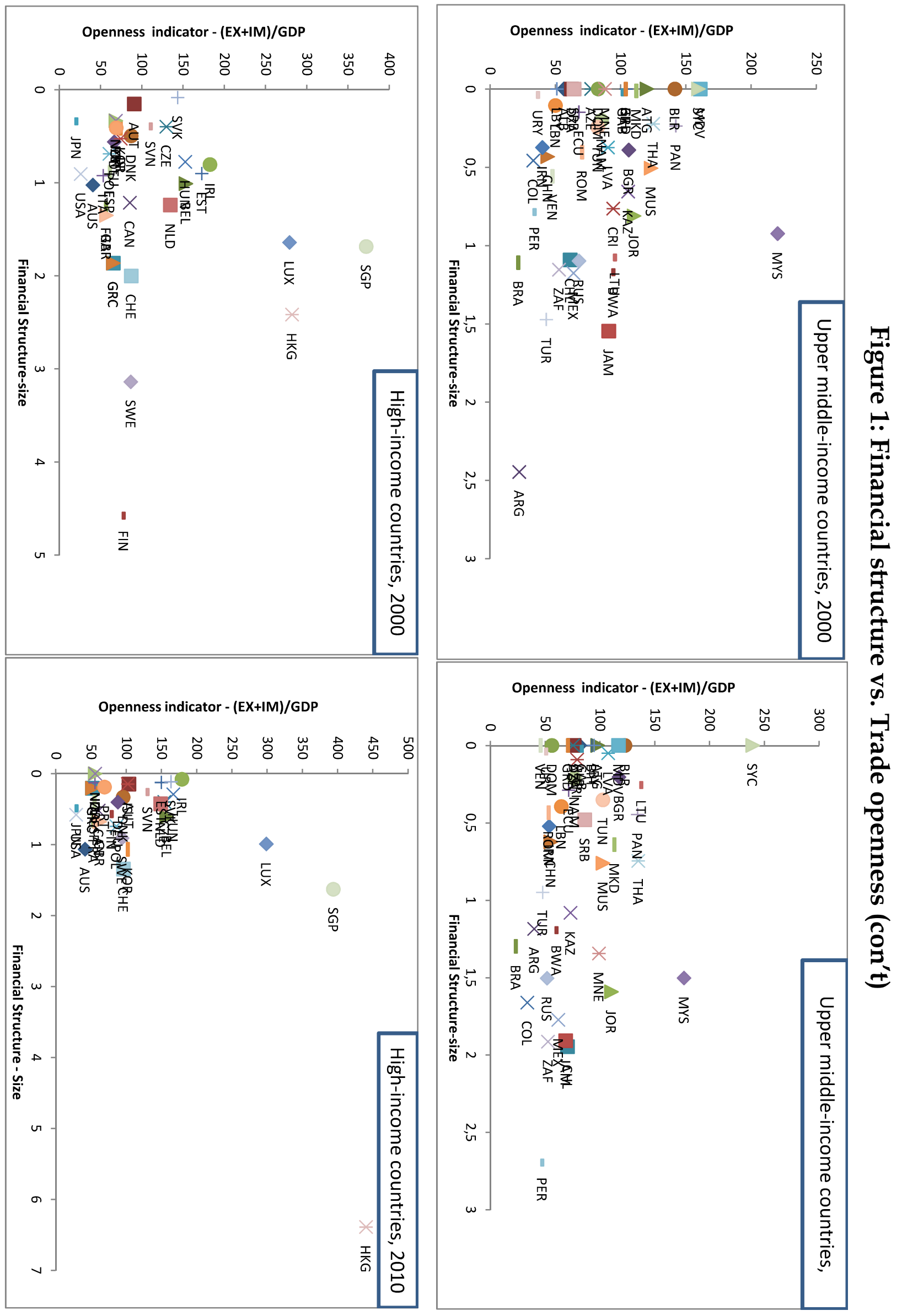

